\title{
Does peripheral concentration of progesterone affect ovulation and lambing rates in Barbados blackbelly ewes?
}

\author{
Ezra Devonish \\ West Virginia University
}

Follow this and additional works at: https://researchrepository.wvu.edu/etd

\section{Recommended Citation}

Devonish, Ezra, "Does peripheral concentration of progesterone affect ovulation and lambing rates in Barbados blackbelly ewes?" (2005). Graduate Theses, Dissertations, and Problem Reports. 2195. https://researchrepository.wvu.edu/etd/2195

This Thesis is protected by copyright and/or related rights. It has been brought to you by the The Research Repository @ WVU with permission from the rights-holder(s). You are free to use this Thesis in any way that is permitted by the copyright and related rights legislation that applies to your use. For other uses you must obtain permission from the rights-holder(s) directly, unless additional rights are indicated by a Creative Commons license in the record and/ or on the work itself. This Thesis has been accepted for inclusion in WVU Graduate Theses, Dissertations, and Problem Reports collection by an authorized administrator of The Research Repository @ WVU. For more information, please contact researchrepository@mail.wvu.edu. 
Does peripheral concentration of progesterone affect ovulation and lambing rates in Barbados Blackbelly ewes?

\section{Ezra Devonish}

Thesis

Submitted to the College of Agriculture and Forestry

At West Virginia University

In partial fullfillment of the requirements for

The degree of

Master of Science

In

Reproductive Physiology

E. Keith Inskeep, Ph.D., Chair

Robert A. Dailey, Ph.D.

Marlon Knights, Ph.D.

College of Agriculture, Forestry and Consumer Affairs

Morgantown, West Virginia

2005

Keywords: sheep, Barbados Blackbelly, progesterone, ovulation rate, litter size, lambing rate 


\section{Abstract \\ Does peripheral concentration of progesterone affect ovulation and lambing rates in Barbados Blackbelly ewes?}

\section{Ezra Devonish}

The hypothesis that concentration of progesterone influences number of follicles that mature during estrus, and thus ovulation rate, was tested in cycling ewes. Ewes were assigned at random to three treatments, and bred at estrus after treatment. Ewes in low (LP) and high (HP) groups received exogenous progesterone from day 4 to 14; control ewes (MP) were untreated. The LP ewes were given $\mathrm{PGF}_{2} \alpha$ on day 6 to regress corpora lutea $(\mathrm{CL})$. Numbers of follicles and $\mathrm{CL}$ were observed by transrectal ultrasonography. Fewer follicles disappeared at estrus in ewes on HP than in MP or LP. Ewes on LP had a greater number of CL compared with MP or HP, which did not differ. Number of $\mathrm{CL}$ increased, but lambs born per $\mathrm{CL}$ decreased linearly with decreasing concentrations of progesterone; therefore litter size was not changed. In conclusion, LP increased ovulation rates, but did not increase prolificacy. 


\section{Acknowledgements}

I would like to thank the members of my committee Drs. Robert Dailey and Marlon Knights for their support and guidance, which allowed me to grow as a scientist. In addition, my sincere appreciation to Dr. Knights for his tremendous support in the acquisition of the knowledge of ultrasonography at West Virginia University, with further training at Greenland Livestock Research Station, Barbados, which allowed me to successfully complete the second replicate of this study.

Sincere appreciation is also extended to Dr George Seidel who was very supportive and gave me excellent cooperation in the statistical analysis of the data and Dr Brett Kenney for his adding breadth to my educational experience by exposure novel meat technologies.

Special thanks to Ida Holaskova, who was supportive in my overcoming the many challenges in West Virginia that a new student is faced with.

Completion of my research studies would not have been possible without the help of my fellow graduate students, particularly, Ms Aimee Wurst and Mr Justin Rhinehart.

I wish to express my gratitude to the staff of the Ministry of Agriculture and Rural Development Mr Barton Clarke, Michael Hunte, $\operatorname{Dr}$ Dennis Blackman and the Department of Veterinary Services of Barbados, especially Dr. Rosina Maitland, Mr Arthur Skeete for their help in the execution of my research protocol. Special thanks to Mrs June Roach and Ronna Watson for their invaluable assistance with the running of the progesterone assays. The Staff of Greenland Livestock Research Station especially, Mr Gerry Thomas, Mr. Gregory Welch, Ms Valerie Edwards and Antonio Hurst for their 
furtherance of my research.

Finally, the author is grateful to Evangeline Ragoonath- Devonish, my wife, for her ceaseless encouragement, patience and perpetual love. 


\section{Dedication}

My journey to a successful graduate career began with this advice from Dr Inskeep, my mentor, "A good researcher is unbiased and a dispassionate observer". His constant quest for me to reach my full potential was ascertained through constructive criticism, appreciation of experimental design and statistical analysis. My challenge was to develop proficiency in verbal and written communication. However, the task was made easier, but at times intimidating, by his incisive literary skills gained from over 40 years experience of writing manuscripts or editing journals. I was deeply moved, that even during his illness, he was still concerned with the well being of all his students. His unending zeal and support of each student's career objectives and to maximize their knowledge in order that each may reach their full potential. I was blessed to be one of those students. As I continue my journey to follow in the huge footsteps of my mentor, who has succeeded in giving me some of the tools, which I will need to work in a challenging environment such as a small Caribbean island (Barbados). "I would like to thank my mentor Dr Inskeep for his patience, unending generosity and guidance, which allowed me to acquire the skills required to become a scientist. 


\section{Table of Contents}

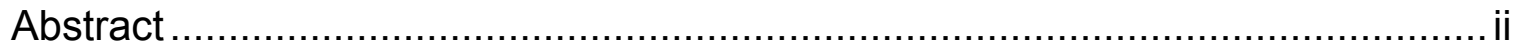

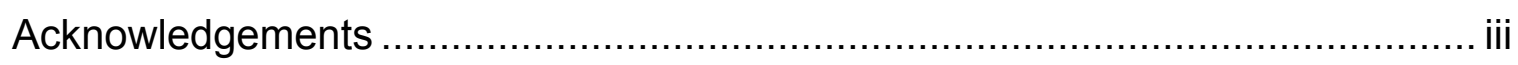

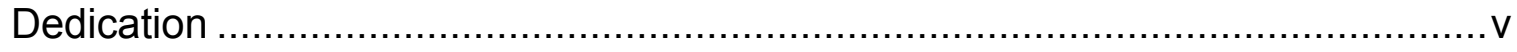

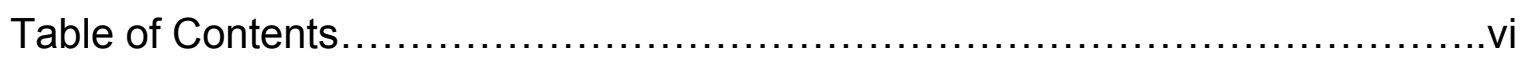

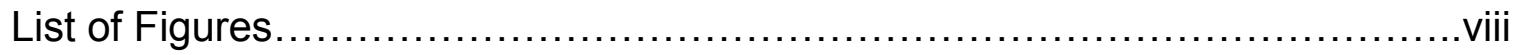

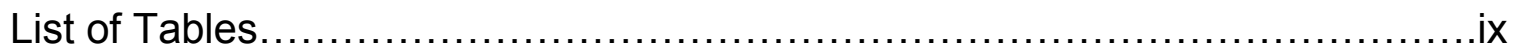

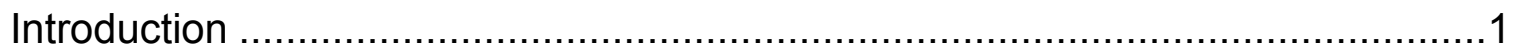

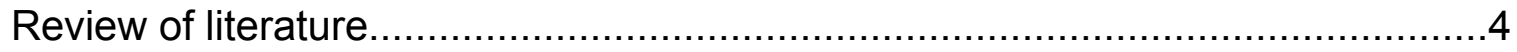

Characterization and regulation of the events in the estrous cycle ................4

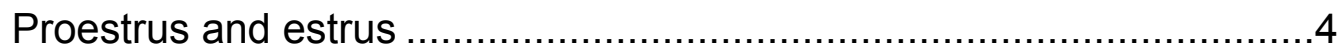

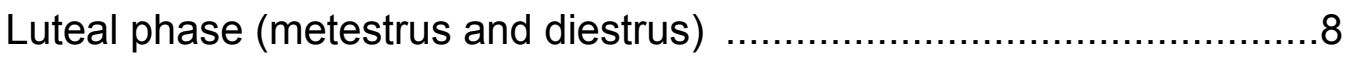

Follicular growth and development during the estrous cycle ...........................

Role of follicle stimulating hormone (FSH) in follicular growth and ovulation rate

The resting pool

Follicular recruitment, follicular waves and dominance .........................

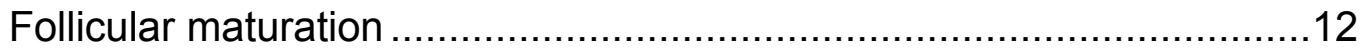

Effects of progesterone on follicular development.............................13

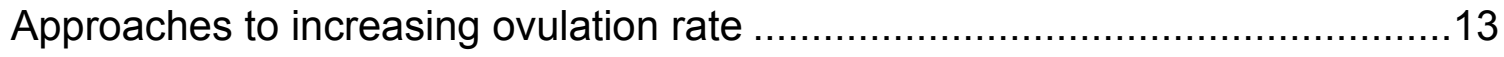

Breeds and genetic mechanisms involved in prolific and non-prolific.....14

Hormonal approaches: Use of FSH ….......................................15

Hormonal approaches: Exogenous progesterone .............................17

Effects of age and nutrition on ovulation rate and litter size ................18 
Immunological approaches: antibodies .......................................19

Pre and post-ovulatory factors that affect lambing rate .................................20

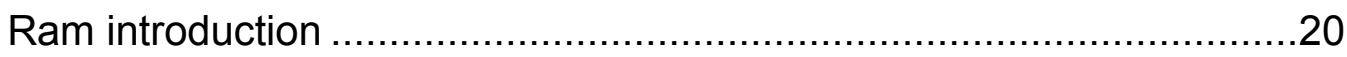

Hormonal, environmental factors and age of ovulatory follicle .............21

Actions of progesterone on the uterus and embryogenesis ................22

The origin of hair sheep and breed characteristics ......................................25

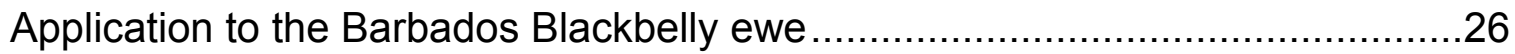

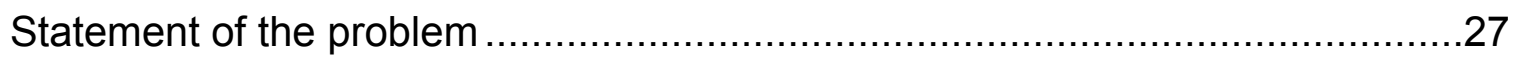

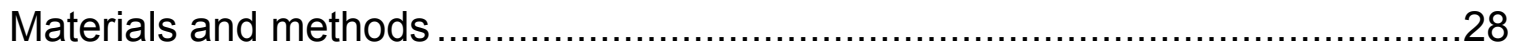

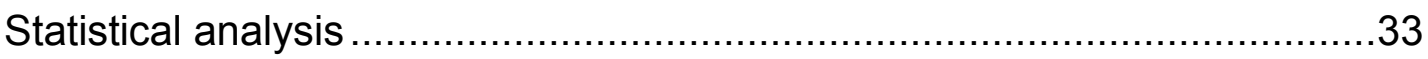

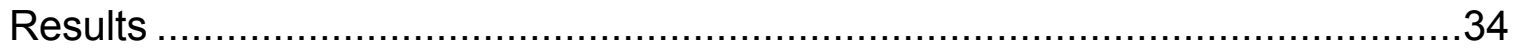

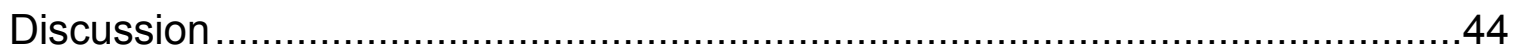

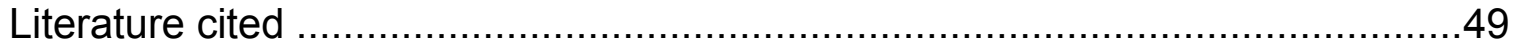

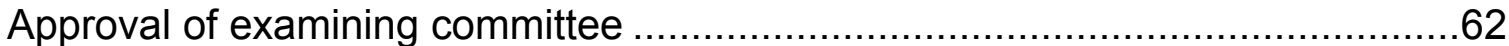




\section{List of Figures}

Figure 1 Concentrations of progesterone $(\mathrm{ng} / \mathrm{ml})$ relative to day 0 in ewes treated to have high, medium or low progesterone. 32

Figure 2. Numbers of total follicles and numbers in each size class on days 4 through 16 in ewes on high (A), medium (B), or low (C) progesterone summed over both ovaries.

Figure 3. Numbers of follicles in each size class prior to ovulation. .38

Figure 4. Number of disappearing follicles in ewes with high, medium or low concentrations of progesterone.

Figure 5. Mean growth rates of disappearing follicles in the final and penultimate waves in low, medium and high progesterone treatment groups. 40

Figure $6 \mathrm{~A}$. Mean number of $\mathrm{CL}$. 43

B Lambs born per CL. .43

C. Number of lambs born per ewe lambing. .43

Figure 7 The lambing patterns of ewes with high, medium and low concentrations of progesterone 


\section{List of Tables}

Table 1. Occurrence of estrus and ovulation rates in Barbados Blackbelly ewes in response to low, medium or high circulating concentrations of progesterone

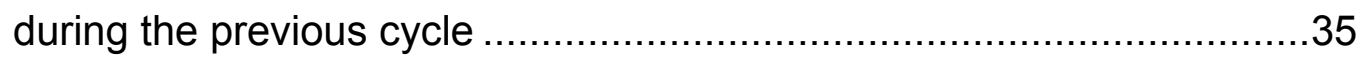

Table 2. Time from emergence to disappearance of presumed ovulatory follicles from

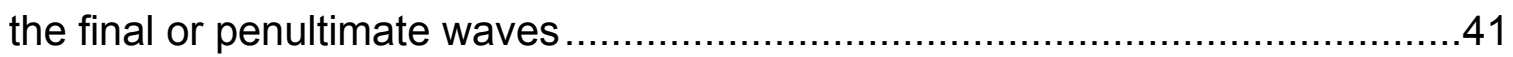




\section{Introduction}

The estrous cycle and its components have been characterized in many breeds of sheep. Studies conducted mainly in temperate regions of North America, Europe, Australia and New Zealand with breeds of sheep that originated within those regions have resulted in the identification of breeds with differing levels of prolificacy. Prolific breeds, in contrast to non-prolific breeds, have smaller ovarian follicles (Driancourt et al., 1990, 1996; Bartlewski et al., 1999; Gibbons et al., 1999), with fewer layers of granulosal cells per follicle (Driancourt et al., 1990, 1996), reduced numbers of atretic follicles (Turnbull et al., 1978; Mandiki et al., 2000), and lower peripheral concentrations of progesterone and estradiol (Avdi et al., 1997; Reynaud et al., 1999; Bartlewski et al., 2003). Thus, lower circulating concentrations of progesterone are associated with higher ovulation rates.

The evolution of breeds has resulted in a diverse gene pool from which to select traits (carcass, wool and milk) for genetic improvement. Breeding programs have been successful in increasing fertility. However, an increase in prolificacy through genetic selection is a slow process, For example, development of the relatively high prolificacy in the Barbados Blackbelly sheep started in the year 1657, upon the introduction of parent stock onto the island of Barbados (Ligon R., 1657), and evolved over 300 years. Regardless of the production traits of interest, the ability to have multiple offspring depends on reproductive management techniques to facilitate increased ovulation and lambing rates (prolificacy).

An ovulation rate of one or two follicles is the usual species specific number for sheep. A reproductive management technique to increase prolificacy quickly will be 
advantageous to producers, by providing increased revenue from lambs sold and more breeding stock. Attempts to manipulate ovulation rate through the use of exogenous gonadotropins have had limited success, partly due to differences in breed responsiveness (Saumande et al., 1978), $\mathrm{FSH} / \mathrm{LH}$ ratio of the gonadotropin used (Chupin et al., 1984), and variation in the response based on the day of the cycle when stimulation was begun (Sreenan et al., 1978).

Although pregnancy rates, percent ewes lambing, and lambing rates to first service were not different, anestrous ewes treated with progesterone had higher overall lambing rates than the controls, and ewes treated with progesterone and FSH tended to have greater prolificacy than those treated with progesterone only (Knights et al., 2001). In another study, Knights et al. (2003) treated anestrous ewes with progesterone inserts (controlled internal drug-releasing device; $C I_{D R}-G^{\circledR}$ ), for induction of estrus, for 5 days; at the removal of the insert, rams were introduced. A single injection of $\mathrm{FSH}$ at $12 \mathrm{~h}$ before removal of the insert resulted in a small increase in ovulation rate, but no overall effect on pregnancy rate or prolificacy. However, the highest dosage used in the study would have elicited a superovulatory response when given in the breeding season. Interestingly, from both studies, the authors suggested that the combination of progesterone and ram introduction was as effective as adding low dosages of $\mathrm{FSH}$ to those treatments in increasing prolificacy during the anestrous season.

Use of gonadotropins often has resulted in release of an unpredictable number of ova, at different stages of follicular development, leading to decreased fertility and high embryonic loss (Lunstra and Christenson, 1981). One possible alternative might be to use exogenous progesterone/progestogen to increase ovulation rate. Subluteal 
concentrations of progesterone were shown to influence the recruitment of follicles, endocrine patterns and follicular waves during the luteal phase of the ewe (Johnson et al., 1996; Viñoles et al., 1999), and the number of follicles ovulated (Bartlewski et al., 1999).

Concentration of progesterone during the luteal phase was relatively high in a non-prolific breed (Western white-face) and low in a prolific breed (Finn ewes) (Bartlewski et al., 1999). Studies of follicular dynamics in less-prolific breeds, for example, the Western white-faced (Bartlewski et al., 1999; Duggavathi et al., 2001; Bartlewski et al., 2003) and Suffolk (Bister et al., 1999), have shown that ovulatory follicles arose predominantly in the follicular wave prior to estrus. In contrast, Bartlewski et al. (1999) found that, in prolific Finn ewes, follicles were ovulated from the penultimate wave of follicular development as well. In addition, Bartlewski et al. (1999) found that ovulation rate was increased by $50 \%$ in Western white-faced ewes treated with medroxyprogesterone acetate (MAP), to simulate low concentrations of progesterone after regression of the corpora lutea. They postulated that lifespan of the largest follicles in the penultimate wave was increased, which allowed them to ovulate with those in the final wave (Bartlewski et al., 1999). Johnson et al. (1996) observed ovulatory follicles emerging as early as day 9 or as late as day 15 in ewes of mixed breeding that had been selected for twinning, supporting the hypothesis that follicles from different cohorts could survive to ovulate. Effects of experimental manipulations of concentrations of progesterone during the breeding season on ovulation rate and prolificacy in ewes with naturally greater ovulation rates have not been reported.

Embryonic loss can negate or reduce any improvement in reproductive efficiency 
induced by an increased ovulation rate. Hulet et al. (1956) estimated embryonic and fetal loss from day 18 to term to be $9 \%$; other authors have stated that embryonic losses after day 30 were low (Robinson, 1951; Quinlivan et al., 1966). In contrast, fetal loss after day 50 was estimated to be approximately $78 \%$ for ewes with ovulation rates that exceeded 6 oocytes (Quinlivan et al., 1966) and 19\% for those that had ovulation rates of 5 or fewer oocytes (Rhind et al., 1980). Nevertheless, if low progesterone before breeding increases ovulation rate by a nominal amount, it might be possible to increase litter size.

\section{Review of Literature}

\section{Characterization and requlation of the events in the estrous cycle}

The length of the estrous cycle is approximately 17 days in ewes. As summarized by Goodman (1994), regulation of length of the estrous cycle is dependent upon inter-relationships among the hypothalamus, the anterior pituitary, the ovary and the uterus. The estrous cycle is divided into four phases; proestrus, estrus, metestrus, and diestrus.

\section{Proestrus and estrus}

During proestrus, the decline of progesterone releases the hypothalamohypophyseal axis from negative feedback inhibition (Baird and Scaramuzzi, 1976; Karsch et al., 1979; 1980) on tonic secretion of $\mathrm{GnRH}$, which results in a concomitant increase in $\mathrm{LH}$, which in turn increases secretion of estradiol from the ovulatory follicle (Scaramuzzi et al., 1977). However, progesterone 'priming' is a prerequisite for the expression of estrus and the subsequent LH surge, which is required to cause 
ovulation. Even though estradiol might induce estrus in the absence of progesterone 'priming, a higher dosage is required. Progesterone pretreatment in ovariectomized ewes reduced the interval from estrogen treatment to the onset of estrus, in addition to which it increased the number of animals that responded to estrogen and subsequent repeated treatments with estrogen (Robinson, 1954b; 1955). Interestingly, repeated use of estradiol under circumstances of a short time period (intervals of days) has resulted in a reduction of the estrous response (Robinson, 1954a; Scaramuzzi et al., 1972).

The decline of progesterone is due to the regression of the CL (luteolysis). The regression of the $C L$ (and alternatively the maintenance of pregnancy) is regulated by the timing and changes in amplitude of the secretion of prostaglandin $F_{2} \alpha\left(\mathrm{PGF}_{2} \alpha\right)$ by the uterus. Even though the uterus secretes $\mathrm{PGF}_{2} \alpha$ continuously throughout the estrous cycle, its episodic secretion increases beginning on day 11 to 12 (Ottobre et al., 1984). These episodes of $\mathrm{PGF}_{2} \alpha$ initiate a decline in progesterone. The removal of the main source of estrogen (follicles) by X-irradiation of the ovaries on days 5 or 6 or cauterization of follicles on day 13 delayed luteolysis (Karsch et al., 1970). Gengenbach et al. (1977) found that estrogen and $\mathrm{PGF}_{2} \alpha$ given simultaneously, were more effective in luteolysis than either separately in hysterectomized ewes with X-irradiated ovaries. Thus, the $\mathrm{CL}$ is regressed by $\mathrm{PGF}_{2} \alpha$ and estradiol, both functionally and structurally (Gengenbach et al., 1977; Griffeth et al., 2002).

The CL will regress in response to $\mathrm{PGF}_{2} \alpha$ by day 5 (Houghton et al., 1995). Acritopoulou et al. (1980) treated ewes on days $3,5,8,11,14$ or 16 of the estrous cycle and concluded that the corpus luteum of the ewe was responsive to $\mathrm{PGF}_{2} \alpha$ only between days 5 through 14 of the estrous cycle. They found that intervals to the onset 
of estrus were 33,40 and $46 \mathrm{~h}$ for ewes treated with $\mathrm{PGF}_{2} \mathrm{\alpha}$ on days 5 , 8 , or 11 postestrus, respectively, and that the LH surge occurred approximately 10 to $11 \mathrm{~h}$ after onset of estrus. Deaver et al. (1986) postulated two mechanisms through which the interval from luteolysis to estrus can be influenced. First, the variability in response could be attributed to differences in sensitivity of the hypothalamic-pituitary axis to the positive effects of estradiol. This effect might be mediated by either the concentration of progesterone or the ratio of progesterone to estradiol on the days of the cycle when the ewes were treated. For example, Reeves et al. (1970) showed that highly purified porcine $\mathrm{GnRH}$ induced the release of $\mathrm{LH}$ from the pituitary in the female and castrated male sheep. Estradiol sensitizes the pituitary to $\mathrm{GnRH}$ and mediates the release of LH by a positive feedback to the hypothalamus (Goodman and Karsch, 1980). GnRH is released from the median eminence of the hypothalamus and regulates the pituitary release of LH in both tonic and acute patterns. The maximal response in a diestrous ewe or a ram given $81 \mu \mathrm{g} \mathrm{GnRH}$ was $12 \mathrm{ng} / \mathrm{mL}$ above pre-treatment concentrations of $\mathrm{LH}$, but when $27 \mu \mathrm{g} \mathrm{GnRH}$ was given to wethers, it resulted in a peak concentration of $160 \mathrm{ng} / \mathrm{mL} \mathrm{LH}$. The lack of a significant dose response in the ewe was due to the inhibition by progesterone. In addition, the intact ram produces testosterone, which has a negative feedback at the pituitary, unlike the wether, that has no progesterone or testosterone to inhibit the response (Reeves et al., 1970). This finding supports the inhibitory effects of progesterone (ewe) and testosterone (ram) on the pituitary responsiveness to $\mathrm{GnRH}$.

The pre-ovulatory rise in estradiol might mediate a change in pituitary responsiveness to $\mathrm{GnRH}$. Arimura et al. (1971) showed an increase in pituitary 
responsiveness to exogenous $\mathrm{GnRH}$ in the intact female rat pretreated with estradiol benzoate. The responsiveness of the pituitary to $\mathrm{GnRH}$ was greatest on the day of estrus, presumably because estradiol had been elevated (Reeves et al., 1971). This was attributed to an increased pituitary sensitivity to $\mathrm{GnRH}$, due to both an absence of inhibiting effect of progesterone and a stimulating effect of estrogen. Padmanabhan et al. (1978) incubated bovine pituitary cells with estradiol-17 $\beta$ for 4 or $28 \mathrm{~h}$ and exposed them to $\mathrm{GnRH}(0$ and $100 \mathrm{ng} / \mathrm{ml}$ ) during the final $2 \mathrm{~h}$ of incubation. Incubation of pituitary cells with $\mathrm{E}_{2}$ for $2 \mathrm{~h}$ followed by $\mathrm{GnRH}$ did not affect $\mathrm{LH}$ secretion. In contrast, all concentrations of $\mathrm{GnRH}$ tested stimulated $\mathrm{LH}$ secretion in cells pre-treated with $\mathrm{E}_{2}$ for 26 hours. The authors concluded that an increased concentration of $E_{2}$ for a period of time was required for the $\mathrm{GnRH}$ induced-release of basal $\mathrm{LH}$. Similar findings were later reported by Moss et al. (1980) and helped to explain the positive feedback by $E_{2}$ that triggers the LH surge. In contrast, pulsatile frequency of tonic LH is regulated by estradiol negative feedback on $\mathrm{GnRH}$ in anestrous ewes and by progesterone negative feedback in cyclic ewes.

LH stimulates those follicles that have acquired LH receptors and are responsive to increased tonic LH secretions. As a result, follicular secretion of estradiol-17 $\beta$ rises and eventually peaks. However, despite major influences of estradiol on the duration of estrus and timing of the LH surge, it has little effect on the intensity of estrous behavior (Fabre-Nys and Martin, 1991).

Behavioral estrus, which lasts for about a day, is influenced mainly by the time of progesterone withdrawal and rate of change and timing of concentrations of estradiol. During estrus, concentration of estradiol falls abruptly, immediately after the LH surge, 
which induces ovulation.

Based upon the above observations, estrus, ovulation and timing of the LH surge (Dutt and Casida, 1948; Karsch et al., 1980) are determined not only by estrogen production by the ovulatory follicle (Scaramuzzi et al., 1971), but also by the initial concentrations of progesterone when luteolysis is initiated (Acritopolou et al., 1977; Deaver et al., 1983).

\section{The luteal phase (metestrus and diestrus)}

The luteal phase (metestrus and diestrus) is the longest period of the cycle, approximately 13 to 14 days. Metestrus follows estrus and lasts for one to two days. During this period, concentrations of both estrogen and progesterone are relatively low. The ovulated follicle undergoes luteinization of thecal and granulosal cells, which results in the formation of the CL (Niswender et al., 1985). This process results in a gradual increase in concentration of progesterone, which occurs as the CL forms over a period of approximately four days (Britt, 1989). The first four days after estrus are characterized by a small rise in estradiol, attributed to the first cohort of follicles, until the gradual rise in progesterone suppresses LH pulse frequency.

The remainder of diestrus is characterized by high concentrations of progesterone and low concentrations of estrogen. Peripheral concentrations of progesterone begin to increase around day 3 after ovulation, which coincides with the activation of the newly-formed CL. Maximum concentrations of progesterone occur around day 10 to 12 and are maintained through day 14 to 15 (Scaramuzzi et al., 1993). The rise in progesterone sets the timing of increased uterine secretion of $\mathrm{PGF}_{2} \mathrm{\alpha}$, which begins around day 12 or 13 and initiates luteal regression by day 15 , which signals 
entrance into pro-estrus and the start of a new estrous cycle. In a mated ewe, a viable conceptus produces interferon-tau and other factors that prevent the regression of the $\mathrm{CL}$, such that pregnancy is recognized and luteal function is maintained (Spencer and Bazer, 2002).

\section{Follicular growth and development during the estrous cycle}

Role of follicle stimulating hormone (FSH) in follicular growth and ovulation rate.

The resting pool. At any one time, it has been suggested that there are 50 antral follicles in the ovaries of adult ewes (Cahill et al., 1979; McNatty et al., 1982; Driancourt et al., 1986). Growth of the selected follicles during a wave initiated by an increase of FSH is maintained by LH, once they have developed LH receptors (Scaramuzzi et al., 1993). However, breeds with high ovulation rates have more growing follicles than breeds with low ovulation rates (Cahill et al., 1979). The number of primordial follicles laid down at birth constitutes a resting pool from which the first growing follicles are recruited at about 70 days of gestation (Mariana et al., 1991). These follicles undergo maturational changes in both morphology and size and are classified as primary, secondary and tertiary. However, even after puberty, relatively few follicles progress to the tertiary stage and even fewer to ovulation; many undergo atresia during the primary and secondary stages. The development of follicles from the resting stage to preovulatory stage requires 34 to 43 days (Turnbull et al., 1977; Cahill and Mauleon, 1980). The mechanism that determines which follicles are recruited from the resting pool is not understood.

Follicular recruitment, follicular waves and dominance. The proposed mechanism of preovulatory folliculogenesis begins with recruitment of small antral follicles from the 
resting pool. One or more of the antral follicles are eventually selected to continue maturation, ultimately being ovulated or becoming atretic (diZerega and Hodgen, 1981; Driancourt et al., 1984). All follicles in a cohort in the ewe arose within a span of 2.3 to 3.0 days (Ginther and Kot 1994; Bartlewski et al., 1999).

Follicle stimulating hormone is required for the recruitment of antral follicles into a growing pool (Picton et al., 1990). In hypophysectomized and unilaterally ovariectomized ewes, Dufour et al. (1979) found that the population of preantral follicles (0.1 mm diameter) was regulated by gonadotropins. In contrast, McNatty et al. (1990) found a significant reduction in the weight of the ovary, but no reduction in the total number of antral follicles ( $2 \mathrm{~mm}$ diameter) for as long as 70 days after ewes were hypophysectomized.

The existence of a wave-like pattern of growth of follicles in sheep is equivocal. For example, Turnbull et al. (1977) postulated that continual growth and regression of follicles occurred during the estrous cycle, an observation supported by (1) the presence of normal and atretic follicles of various sizes on each day of the cycle, (2) the unpredictable time of appearance of very large diameter follicles during the luteal phase of different ewes, and (3) growth of the ovulatory follicle can occur at any stage of the estrous cycle upon removal of the corpus luteum. The latter finding corroborated the earlier results of Smeaton et al. (1971) and was supported later by Lahlou-Kassi et al. (1984), and by Schrick et al. (1993) and Ravindra et al. (1994), who followed follicles with ultrasonography.

In ultrasonographic studies that were restricted to only larger follicles ( 3 to $\geq 5$ $\mathrm{mm}$ in diameter), a wave-like pattern emerged (Ginther et al., 1994; Leyva et al., 1998b; 
Souza et al., 1998). With this restriction, follicles appeared to be recruited and undergo growth and atresia in patterns of two, three (Noel et al., 1993) or four waves during the luteal phase (Ginther et al., 1994). Duggavathi et al. (2005) treated ewes with FSH between expected endogenous peaks of $\mathrm{FSH}$ and found that recruitment of additional cohorts of follicles into the growing phase, did not modify either the endogenous peaks of FSH or the effect of those peaks on recruiting cohorts of follicles. Thus the regulatory mechanism that initiates follicular recruitment in sheep may be different from that in cattle.

The term follicular dominance is used to define the inherent capacity of a follicle to prevent the growth of other follicles on both ovaries without compromising its own growth (Driancourt, 1991, 1994; Webb et al., 1999). Follicular dominance in ewes might be dependent on the stage of the cycle. Duggavathi et al. (2003) suggested that the demise of the ovine CL might be a contributory factor. In their study, the total number of small follicles began to increase two days prior to ovulation and after luteolysis, in agreement with Baird et al. (1978) and Bartlewski et al. (1999). There is other evidence for dominance of ovulatory follicle in the follicular phase as reported by Ravindra et al. (1994) and in later studies (Lopez-Sebastian et al., 1997; Evans et al. 2000; GonzalezBulnes et al., 2001).

Evans et al. (2000) observed that the larger follicle has more estradiol and a higher estradiol: progesterone ratio than the other follicles. In a later study, Evans et al. (2002) postulated that their previous observations might be attributed to follicular dominance. They found that the ablation of the largest follicles on day 4.5 post-estrus resulted in continued growth and increased life span of the second largest follicle, in 
agreement with the earlier studies by Rubianes et al. (1997).

In the luteal phase, Ginther et al. (1994) and Rubianes et al. (1997) found that the largest follicle may prevent the development of other follicles. In sheep, recruitment of follicles $\geq 2 \mathrm{~mm}$ was high at the beginning of the wave and remained low during the growing phase of the largest follicle, but growth of another follicle might occur in the presence of the largest follicle (Viñoles et al., 1999). Other authors also have observed the growth and emergence of follicles in the presence of larger follicles from a previous wave (Schrick et al., 1993; Johnson et al., 1996; Leyva et al., 1998b; Bartlewski et al., 1999; Flynn et al., 2000). Bartlewski et al. (1999) observed that such follicles not only were able to grow, but also to ovulate.

In contrast to the ewe, the evidence for follicular dominance in cattle is more definitive. In cattle, follicular development during an estrous cycle occurs in 2 or 3 waves that involve follicular dominance, which occurs at the point of divergence in size between two largest follicles, along with the suppression of the total number of growing follicles (Ginther et al., 1996). Sufficient dominance exists in cattle that recruitment of new follicles into the growing pool occurs only after the dominant follicle loses its dominance (Adams et al., 1992; Evans et al., 1997). The role of dominance in recruitment of follicles and continued folliculogenesis in the ewe is uncertain and is still debated.

Follicular maturation. Both duration of exposure to secretion of $\mathrm{FSH}$ and sensitivity to $\mathrm{FSH}$ can affect ovulation rate. For example, gonadotropin-responsive follicles have an absolute requirement for $\mathrm{FSH}$ to continue to develop. As these follicles grow, they become gonadotropin-dependent and require increasing concentrations of 
$\mathrm{FSH}$. Once they acquire $\mathrm{LH}$ receptors, they need increasing concentrations of $\mathrm{LH}$, which is controlled by progesterone, as discussed earlier. If they remain viable, a recruited cohort of follicles secretes increasing amounts of estradiol and inhibin, which exert a negative feedback that reduces the secretion of $\mathrm{FSH}$, thus limiting further follicular recruitment. Therefore, the numbers of ovulatory follicles are dependent on sensitivity of the hypothalamo-pituitary axis to the inhibitory effects of estradiol and inhibin on FSH and progesterone on LH (Scaramuzzi et al., 1993).

Effects of progesterone on follicular development.

Progesterone inhibits tonic LH secretion (Baird et al., 1976), thus affecting follicular growth. High concentrations of progesterone limit the growth of the largest nonovulatory follicles in follicular waves during the luteal phase. Those follicles were found by Sirois and Fortune (1988) in cattle, and Noel et al. (1993) in sheep, to be smaller than the largest follicles in the ovulatory wave. These observations were made during the early and late luteal phase when concentrations of progesterone might be low due to early stages of luteinization or the decline in the progesterone output from the CL. Similarly, Brand and de Jong (1973) found that more follicles were recruited at the beginning and end of the estrous cycle, periods of low concentrations of progesterone. That result was supported later by Schrick et al. (1993), based on ultrasonographic observations. All of these findings support the hypothesis that high concentrations of progesterone limit the development of follicles during the luteal phase.

\section{Approaches to increasing ovulation rate}

Breeds and genetic mechanisms involved in prolific and non-prolific sheep. Breed is a 
major factor that determines the ovulation rate (Davis et al., 2001; Montgomery et al., 2001; Bodin et al., 2002; Galloway et al., 2002). McNatty et al. $(2003,2004)$ postulated that the oocyte played a key role in both follicular development and ovulation rate. They suggested that the oocyte controlled-processes that differed between species of low and high ovulation rate phenotypes and that control was mediated by oocyte-secreted factors. This concept may explain why some mammals are more predisposed to multiple or single offspring. The discovery of bone morphogenic protein 15 (BMP 15) and its receptors (BMP 15 is expressed only in the oocytes; reviewed by McNatty et al., 2003) has provided an explanation as to why some breeds are prolific. For example, the Booroola gene involves a mutation in the BMP 15 receptor in oocytes, granulosal cells and luteal cells. Alternatively, genetic changes in sensitivity to FSH have been postulated to influence ovulation rate (Scaramuzzi et al., 1993).

In prolific ewes, two alternative mechanisms have been postulated to account for the occurrence of multiple ovulations. Scaramuzzi et al. (1993) suggested that recruitment of follicles was based on increased sensitivity to $\mathrm{FSH}$ and that support of their continued growth shifted to LH, which stimulates the production of androgen by the theca that is aromatized to estradiol in the granulosa. In this concept, a "window of opportunity" to ovulate is a period during which follicles are sensitive to $\mathrm{FSH}$. In mechanism $\mathrm{A}$, multiple ovulations occur as a result of increased numbers of follicles that retain the ability to respond to gonadotropin (FSH) for a longer period of time (window) and resist atresia. In mechanism $\mathrm{B}$, a greater number of small antral follicles become gonadotropin-responsive in a narrower window of opportunity. Each mechanism is dependent upon the acquisition of $\mathrm{LH}$ receptors by developing follicles, and the two are not mutually exclusive, even though mechanism $A$ is 
dependent on duration of gonadotrophin sensitivity and mechanism B on greater numbers of recruited follicles.

In the prolific Booroola ewe, which carries the $F$ gene, recruited follicles were protected from atresia (Driancourt et al., 1985), and a longer period of recruitment resulted in a greater number of follicles available for ovulation. In contrast, rapid turnover of the largest follicles was observed in monovulatory Merino del Pais ewes (Lopez-Sebastian et al., 1997). In prolific breeds of sheep, such as the Romanov, Booroola, and Finnish Landrace, mechanism A might be responsible for high ovulation rates. There is corroborating evidence that the recruited follicles were maintained longer on the ovary, allowing for a larger number of follicles to be ovulated (Driancourt et al., 1986).

Webb et al. (1989) and Driancourt et al. (1990) reported that the total number of large follicles, on both ovaries combined, at days 13 and 15 of the estrous cycle was similar to the ovulation rate. They attributed the differences in the ovulation rate between the Finn sheep, which were selected for high ovulation rates, and the Merino, to changes in growth and differentiation of the ovulatory follicles. However, these findings were contradicted by Noel et al. (1993), who found that the number of large follicles in Suffolk ewes was 2 to 3 times the ovulation rate. Interestingly, Duggavathi et al. (2003) postulated that ovulation rate was dependent on a stable small follicular recruitment pool that did not change throughout the estrous cycle except around the periovulatory period; these more recent observations were supportive of the previous findings of Webb et al. (1989) and Driancourt et al. (1990).

Hormonal approaches: Use of FSH.

Follicle stimulating hormone regulates the ovulation rate through the number of 
follicles recruited (Driancourt et al., 1991). However, the variability in concentrations of FSH among breeds has created some doubt as to the full extent that it is involved in ovulation rate. Even though both the Romanov and Finn are prolific breeds, the high concentrations of FSH in the Romanov (Cahill et al., 1981) are in direct contrast to the low concentrations in the Finn (Adams et al., 1988). Furthermore, despite the high concentrations of FSH in the prolific Booroola Merino (McNatty et al., 1987), the ovulation rate is dependent on the presence of a major gene, which regulates the increased concentrations of progesterone secreted from an increased number of $\mathrm{CL}$ (luteal tissue; McNatty et al., 1990). Thresholds in responsiveness to FSH among follicles and within ewes might explain some of the high variability in ovulatory response to FSH. Fry et al. (1996) observed three groups of ewes; group 1 had three successive estrous cycles in which ovulation rates were the same, group 2 had three different ovulation rates during three cycles and group 3 had the same ovulation rate in two of the three estrous cycles. However, they were unable to identify thresholds in FSH concentrations associated with changes in ovulation rate; they attributed the inability to determine a threshold to variation in response of the individual follicles within a ewe.

The direct effect of gonadotropin preparations on the follicle was greater for the less acidic isoforms of $\mathrm{FSH}$, even though the number of women who became pregnant, with respect to different isoforms in preparations used for treatment, did not differ (Andersen et al., 2004). Therefore, responsiveness within ewes could be confounded by isoform (whether more or less acidic), when ewes are treated with exogenous gonadotropins that might contain different isoforms of FSH. Exogenous gonadotropins have improved prolificacy in some cases, but their high cost and unpredictable 
responses have resulted in limited adoption in general reproductive management of livestock.

Hormonal approaches: Exogenous progesterone. Ovulation rates are influenced by concentrations of progestogen (Robinson et al., 1968; Allison et al., 1970). In comparing ewes on high and low dosages of progesterone, larger follicles were found in ewes treated with low progesterone (Dutt and Casida, 1948). Synchronization of estrus in ewes with a single sponge containing progestogen (60 mg medroxyprogesterone acetate) from days 5 to 19 (long-duration) produced fewer medium-sized follicles at the time sponges were removed (day 19) than in ewes treated with multiple progestogen sponges (day 5 and replaced on days 10 and 15; Flynn et al., 2000). They postulated that low concentrations of progesterone caused the development of aged follicles (dominant), which prevented further recruitment of small follicles, thus fewer small follicles were available to progress into medium follicles, and the number of large did not change. However, three of the eight ewes studied grew follicles from $3 \mathrm{~mm}$ to $4 \mathrm{~mm}$ even though a large follicle was present. In another study, ewes had their endogenous source of progesterone removed (Johnson et al., 1996) and were implanted with subcutaneous packets of progesterone in silastic. Ewes exposed to low concentrations of progesterone had greater LH pulse frequency and increased concentrations of estradiol, and they ovulated older (larger) follicles than control ewes. Similar results were found by Levya et al. (1998) and Viñoles at al. (1999). These findings might explain the reduction in pregnancy rate observed with ewes on low concentrations of progesterone (Johnson et al., 1996). 


\section{Effects of age and nutrition on ovulation rate and litter size.}

The plane of nutrition of ewes prior to mating can influence ovulation rate. Bramley et al. (1976) observed that ewes, fed either on a low nutritional plane for six weeks prior to mating and for four weeks postmating (LL), or on a low nutritional plane for three weeks and then on a high nutritional plane (LH), or on a high nutritional plane throughout $(\mathrm{HH})$, had significant differences in ovulation and lambing rates. There were linear increases in body weight, body condition score, ovulation rate and lambing rate for $\mathrm{LL}, \mathrm{LH}$ and $\mathrm{HH}$, respectively. This phenomenon was referred to as the flushing response, which occurred in ewes on an increased plane of nutrition before mating. The flushing response might be due to an induced increase in hepatic concentration of mixed function oxidase enzymes, which could increase the metabolism of steroids, reducing the inhibition to the hypothalamic-pituitary axis, and result in the secretion of more gonadotropins and increased numbers of ovulations and lambs (Thomas et al., 1987). In a later study, Nottle et al. (1997) observed a significant interaction between previous nutrition imposed 6 months prior to ovulation and lupin supplementation during the estrous cycle immediately before ovulation. Supplementation with lupins increased ovulation rate by 0.22 in ewes on a low plane, but not in ewes on a high plane of nutrition. Ewes on the high plane of nutrition exhibited higher ovulation rates but a lower conception rate to synchronized estrus than ewes on the low plane. Interestingly, the body condition score also influenced embryo survival. Ewes on the low plane with two or three ovulations had fewer lambs than ewes on the high plane. The authors concluded that uterine efficiency among ewes with multiple ovulations was higher for ewes with good body condition scores at mating regardless of post-mating nutrition. 
Age at first breeding can affect the reproductive efficiency of the ewe. Quirke et al. (1985) observed that ovulation rates (CL count) in each of two consecutive estrous cycles were greater for ewes two years of age and over compared to yearlings. Body size and uterine capacity might be the first limiting factors for the reduction in lambs born to yearlings. In conclusion, flushing is a mechanism that can be utilized to increase ovulation rate and litter size, but there are limits to increases in litter size other than ovulation rate.

Immunological approaches: antibodies. Active immunization of sheep against steroids and inhibin increased ovulation rate. Estrogen is a negative feedback inhibitor of $\mathrm{LH}$ and $\mathrm{FSH}$, thus immunization against estradiol would result in an increase of both of these gonadotropins (Scaramuzzi, 1994). In contrast, immunization against androstenedione increased LH secretion but had little or no effect on FSH (McNatty et al., 1988). The ovaries of androstenedione-immunized ewes usually contained two follicles, which doubled the production of inhibin (Campbell et al., 1990a). The relative lack of androstenedione substrate prevented it's aromatization to estradiol (Campbell et al., 1990c). Additionally, the negative feedback effect is partially blocked due to antibodies that bind estradiol and progesterone; thus, plasma LH is increased, while FSH remains the same. The mechanism of how an increase in the ovulation rate occurs is not fully understood.

Immunization against either inhibin or inhibin-enriched follicular fluid immunoneutralized the biological activity of endogenous inhibin (Price et al., 1987). Consequently concentrations of FSH were increased (O'Shea et al., 1989). As a result of increased concentrations of $\mathrm{FSH}$, more follicles were recruited. The use of 
immunization techniques has had limited application on sheep farms; immunogen has been available commercially only in New Zealand and Australia.

\section{Pre and post-ovulatory factors that affect lambing rate.}

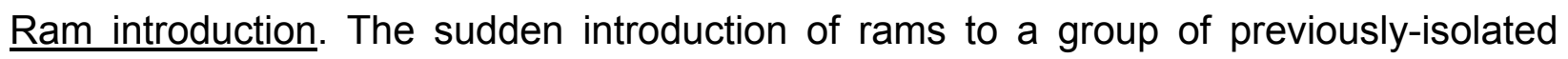
ewes can interrupt anestrus; this is known as the ram effect. The ram induces physiological changes within the ewe that affect hormonal patterns, time to estrus, ovulation rate and fertility. The physiological effects are mediated largely by pheromones (Cohen-Tannoudji et al., 1989; Rekwot et al., 2001) and to a lesser degree through other non-olfactory cues (Cohen-Tannoudji et al., 1989; Pearce and Oldham, 1988). At ram introduction, increased secretion of LH occurred within minutes (Martin et al., 1980; Atkinson and Williamson, 1985; O'Callaghan et al., 1994). Oldham et al. (1978) found that exposure of ewes to a ram resulted in an ovulatory surge that occurred within 6 to $52 \mathrm{~h}$, premature ovulations that varied between 1 to 3 days, and the formation of inadequate or short- lived corpora lutea.

Evans et al. (2004) observed that ram exposure, during the last three days of treatment with $30 \mathrm{mg}$ fluorogestone acetate pessaries for 13 days, advanced the timing of the onset and end of estrus, the LH surge, and ovulation by 2 to $6 \mathrm{~h}$ in crossbred ewes and decreased the duration of estrus compared to the control. However, the ewes exposed to rams before withdrawal of progestogen in one experiment had lower fertility, possibly due to some ewes not being bred during the early-induced estrus. Raddled, intact rams were introduced $48 \mathrm{~h}$ after sponge removal. Fewer ewes were bred in ramexposed versus the control, and of those bred, fewer lambed. Ram-induced LH 
secretion, follicular development, estradiol production, and early onset of estrus might have led to ovulation of aged oocytes and lower fertility, in agreement with the previous findings of Martin et al. (1983). In a second experiment (Evans et al., 2004), ewes received an intravaginal sponge for 14 days and on the $11^{\text {th }}$ day were divided into control and ram-exposed ewes. Rams used during treatment were separated from ewes at sponge withdrawal and breeding rams were introduced $24 \mathrm{~h}$ later.

The responses to ram introduction at progesterone withdrawal were altered from introduction of rams alone. The length of time to onset of estrus was directly related to dosage of progesterone; a larger dose of progesterone resulted in a longer latency period (Robinson and Smith, 1967; Lewis and Inskeep, 1973; Pearce and Robinson, 1985). Parsons and Hunter, $\left(1967^{\mathrm{a}}\right)$ found that estrous periods synchronized by injections of progesterone were shortened by the continuous presence of the rams by 30 to $50 \%$. In another study, Parsons and Hunter, $\left(1967^{\mathrm{b}}\right)$ found that in ewes teased at 4-h intervals (control), ovulation occurred on average shortly after the end of estrus, but the ewes that remained continuously with the rams had a longer interval to ovulation. The authors concluded that there was a correlation between length of estrus and time of ovulation in ewes that were continuously with rams, but not in controls.

Hormonal and environmental factors and age of ovulatory follicle. Embryonic loss can be caused by environmental factors, in particular high ambient temperatures prior to pregnancy recognition (Alliston and Ulberg, 1961; Thwaites et al., 1967) or by low concentrations of progesterone secreted by the $\mathrm{CL}$ and placenta that are required for the maintenance of pregnancy. Embryonic loss was correlated with low concentrations of progesterone $(1 \mathrm{ng} / \mathrm{ml})$, particularly during the period immediately before and after 
maternal recognition of pregnancy (Henricks et al., 1971; Lukaszewska and Hansel, 1980; Lamming et al., 1989; Kastelic and Ginther, 1991). Even though conception rates between 70 to $80 \%$ sometimes have been achieved with synchronization protocols using progestagens (Gordon, 1997), one possible disadvantage is a reduction in the productivity of farming enterprises due to embryonic loss and, consequently a lower weaning rate.

Ovulation of aged follicles can reduce fertility due to a poor quality oocyte, as observed in rats (Butcher, 1972) and in cattle (Stock and Fortune, 1993; Mihm et al., 1999). Induction of luteolysis at the beginning of progestogen synchronization resulted in ewes ovulating old ( 7 to 14 days) or young ( 4 to 5 days) follicles, unlike those that were exposed to high concentrations of progesterone continuously, which ovulated young follicles only ( 3 to 6 days; Flynn et al., 2000). However, in the study by Evans et al. (2001) the age of the follicles had no deleterious effects on birth of live animals. Elevated concentrations of $\mathrm{LH}$, estradiol or both might reduce fertility by the disruption of signaling mechanisms in the oocyte; primarily premature activation of the oocyte (Revah and Butler, 1996; Mihm et al., 1999) or ovulation of an aged oocyte (Roche et al., 1999) in cattle. Research to determine whether estradiol or LH might be responsible for the demise of the early embryo is yet to be done, except in rats. In that species, Butcher and Pope (1979) showed direct effects of estradiol on embryonic development and congenital anomalies.

\section{Actions of progesterone on follicles, the uterus and embryogenesis}

A successful pregnancy is dependent on successful embryogenesis 
(development of the conceptus), which is influenced by extrinsic and intrinsic factors, including endocrine patterns prior to conception. Progesterone might directly (oviduct or uterus) or indirectly (gonadotropins) influence gamete transport (Allison and Robinson, 1972), fertilization (Soede et al., 1994), cleavage, the formation of a morula and a blastocyst (Oussaid et al., 1999), hatching of the blastocyst from the zona pellucida, elongation of the blastocyst and the initiation of attachment during maternal recognition of pregnancy (Lukaszewska and Hansel, 1980; Lee and Ax, 1984; Lamming et al 1989).

Asdell et al. (1949) found that progesterone influenced the remodeling of the myometrium and endometrium of the bovine uterus in preparation for implantation and their findings were corroborated in ewes by Miller and Moore (1983). The latter authors removed explants over the first 10 days of the estrous cycle from the endometrium of untreated ewes and from (pregnant) ovariectomized ewes treated with estradiol and progesterone. When progesterone was given before estradiol, it inhibited the tissue RNA:DNA and protein:DNA ratios in intercaruncular and caruncular endometrium at about 4 to 7 days after estrus. They concluded that embryonic development was impaired in bred ewes that were ovariectomized and did not receive supplemental progesterone.

Ottobre et al. (1980) found that ewes treated with $40 \mathrm{mg}$ progesterone at 8 and $32 \mathrm{~h}$ after onset of estrus (day 0 ) had short cycles (11.0 \pm 1 days) compared to the average cycle length $(17.0 \pm 0.3$ days $)$ in untreated controls. The treatment advanced timing of greater secretion of $\mathrm{PGF}_{2} \alpha$, which began on day 8 , compared to day 12 for the control, and led to early luteal regression and shortened the cycle. The elevation of estrogen at estrus increases the concentration of progesterone receptors; as a result, 
increased progesterone sets the subsequent timing of the secretion of $\mathrm{PGF}_{2} \alpha$ (ewe Ottobre et al., 1980, 1984; postpartum beef cow - Zollers et al., 1993). Short luteal phases in cattle (Cooper et al., 1991) and sheep (Southee et al., 1988) were associated with premature release of $\mathrm{PGF}_{2} \alpha$ from the uterus. Kieborz-Loos et al. (2003) found that oxytocin-induced release of PGFM was inhibited on day 6 after a second exposure to progesterone treatment in postpartum ovariectomized cows, which were treated previously with estradiol-17ß. These authors concluded that both estradiol-17 $\beta$ and progesterone were involved in timing secretion of $\mathrm{PGF}_{2} \alpha$ in the postpartum cow.

Vincent et al. (1986) treated ewes with daily injections of progesterone on days 1 through 3 post estrus and transferred a day-10 blastocyst into the uterus on day- 6 postestrus. One group of control ewes was treated with vehicle and a day-10 blastocyst was transferred into the uterus on day- 6 postestrus. Concentration of $\mathrm{PGE}_{2}$ was elevated beginning on day 8 in progesterone-treated ewes that received a day-10 blastocyst on day- 6 postestrus but did not increase until day 12 in mated pregnant ewes. Interestingly, the authors observed that the uterus in progesterone treated-ewes was able to support a day-10 embryo but not a day- 6 embryo transferred on day-6. Untreated ewes supported a day- 6 but not a day-10 embryo transferred on day- 6 . These observations support the suggestion that progesterone is involved in the coordinated temporal regulation of uterine development. Garrett et al. (1988) observed that 14-day-old conceptuses from beef cows treated with progesterone on days 1 through 4 were more developed with the capacity to produce the maternal recognition protein bTP-1, unlike the untreated controls. In a later study, Albihn et al. (1991) found a correlation between concentrations of progesterone and the development of 17-day-old 
embryos.

Progesterone is involved in the quality of the embryo. Henricks et al. (1971) observed an inverse relationship between plasma concentrations of progesterone during the 2-day period before estrus in the cow and the number of blastomeres in the conceptus 3 days after mating. The interaction of concentrations of progesterone and estrogen can impact the embryo directly or indirectly $(\mathrm{CL})$. The dosage of progesterone required to maintain pregnancy in beef heifers that were ovariectomized, allowed pregnancy loss when given to unilaterally ovariectomized heifers, due to higher concentrations of estrogen in the unilaterally ovariectomized animals (Zimbelman and Smith, 1966). From this observation, it was concluded that elevated concentrations of estradiol inhibited embryo maintenance (Butcher et al., 1992; Maurer and Echternkamp, 1982).

Low progesterone might have a negative impact on embryogenesis indirectly through increased $\mathrm{LH}$ following inadequate formation of the $\mathrm{CL}$. The increase in $\mathrm{LH}$ and the concomitant rise in estradiol might have decreased embryo survival in the sow (Blair et al., 1993). In sheep, Oussaid et al. (1999) found that cleavage and development to the 16-cell stage were impaired by suppressed estradiol during the follicular phase, which was indirectly inhibited by $\mathrm{GnRH}$ antagonist. This might have resulted in reduced implantation and accounted for increased embryonic loss.

\section{The origin of hair sheep and breed characteristics}

Hair sheep comprise $10 \%$ of the world sheep population (Bradford and Fitzhugh, 1983). Their origins and current geographical locations are mainly in South America, 
South Africa and the Caribbean. They are prolific breeders throughout the year (Bradford and Fitzhugh, 1983), with an apparent resistance to internal parasites (Yazwinski et al., 1979), and with lower rectal temperatures (Horton et al., 1991), respiration rates (Ross et al., 1985), dry matter intakes (Warren et al., 1984; Quick and Dehority, 1986) and water intakes than wool breeds (Quick and Dehority, 1986). One breed of hair sheep is the Barbados Blackbelly (BB). The BB coat color ranges from a light fawn to a deep reddish-brown with a black belly, and black markings extending from around the eye to it's polled forehead, the nose and under the chin, and black stockings extending from the inner thigh to the hoof. The BB is a non-seasonal breeder, with a litter size of approximately two lambs (Patterson, 1983) and a $78.5 \%$ lamb survival to weaning (Fitzhugh and Bradford, 1983). The BB evolved from crosses of parent stocks of African hair sheep and European wooled breeds. Ligon (1657) suggested that the origin of the breed was an evolution from these parent stocks, which gave rise to a highly prolific and tropically-adapted breed in Barbados during the first quarter-century of colonization.

\section{Application to the Barbados Blackbelly ewe}

The goal of sheep producers is to maximize efficiency of production through reduction in feed costs, improvements in average daily gain, reduction in morbidity and mortality, and increased reproductive efficiency. A sheep selection program (Greenland Livestock Research Station) has been implemented in Barbados to improve the current average daily gain of $0.31 \mathrm{~kg}$.

General management strategies ensure that nutritional and health care needs 
are met. However, reproductive efficiency and further genetic improvement can be enhanced through the use of artificial insemination (Al) with frozen semen and an efficient synchronization protocol. Synchronized lambing allows producers to be present at lambing and enhances chances to reduce mortality, which occurs at parturition due to hypoxia.

The livestock industry in Barbados consists mainly of small producers with fewer than 25 ewes, and 27 major sheep breeders with approximately 100 ewes each. There is an emerging niche market in the tourism and restaurant sector for fresh Barbados Blackbelly lamb and international requests for frozen semen. The main constraint in development of these markets is the inability to develop production systems that will maximize the inherent prolificacy of the breed, increase production efficiency, and minimize cost of production.

The goal (Barbados Sheep Producers Association) is to have three lambings in two years using timed artificial insemination, thus providing a supply of high quality lamb and sires continuously throughout the year. To help sheep producers achieve these objectives, an efficient method of estrous synchronization must be developed.

\section{Statement of the Problem}

Some protocols for estrous synchronization reduce conception rates through the production of aged oocytes or inadequate estrogen, coupled with the distribution of interval to estrus being too great for timed Al. The effects of progesterone on ovulation and lambing rates were investigated within a breed at a location in which seasonality is not expressed, by varying concentrations of progesterone. Therefore, the confounding factors in many of the studies outlined previously with respect to breed and season 
were removed in this study. The aim was to compare effects of three concentrations of progesterone on ovulation and lambing rates. Controlled internal drug releasing devices (CIDR) impregnated with progesterone were used to create low and high concentrations of progesterone. Van Cleeff et al., (1998) measured concentrations of progesterone of $3.3 \pm 0.2 \mathrm{ng} / \mathrm{ml}$ (range, 1.0 to 5.9 ) and $2.7 \pm 0.3 \mathrm{ng} / \mathrm{ml}$ (range 1.4 to $8.5 \mathrm{ng} / \mathrm{ml}$ ) at CIDR insertion on approximately day 8 of the estrous cycle (10 days after $P G F_{2} \alpha$ ), and removal ( 8 days after insertion), respectively. In the present study, high concentrations of progesterone were achieved by insertion of a CIDR in ewes with intact CL. Low concentrations of progesterone were brought about by insertion of a CIDR, followed by removal of the $\mathrm{CL}$ by $\mathrm{PGF}_{2} \mathrm{\alpha}$, and medium concentrations were expected in ewes with an intact CL only. In a subset of ewes within each treatment group, the follicles were followed from recruitment to ovulation by ultrasonography. Embryonic and fetal survivability was determined by the number of lambs born per CL counted at 7 days after post-treatment estrus.

\section{Materials and Methods}

The experiment was conducted in Barbados (latitude $10^{\circ} \mathrm{N}$ ) with 168 Barbados Blackbelly ewes in two replicates. Sixty nine ewes were studied in the dry season (December, 2003) and 99 in the wet season (July, 2004). The ewes had average ages of 2.5 years, parities of 1.8 and body weights of $43 \mathrm{~kg}$, which did not differ among treatments or between replicates. The ewes were penned in an enclosed barn and received a daily maintenance ration of $2 \mathrm{~kg}$ of concentrates (corn, soybean meal and minerals formulated to contain $18 \%$ crude protein), with water and pangola hay ad libitum. 
Ewes were randomized to three treatment groups (low, medium, or high progesterone) of 23 or 33 ewes each for replicates 1 and 2, respectively. All ewes were treated twice, 8 days apart, to synchronize estrus before the study. Each time they were given two injections of $5 \mathrm{mg} \mathrm{PGF}{ }_{2} \mathrm{a}$ (Lutalyse ${ }^{\circledR}$, Pfizer Animal Health) 3 hours apart, which mimics the natural episodic secretion of $\mathrm{PGF}_{2} \mathrm{\alpha}$ by the uterus (and by the $\mathrm{CL}$ in response to uterine $\mathrm{PGF}_{2} \alpha$ ). Ewes that were between estrus and the 4th day of their cycle would have non-responsive $\mathrm{CL}$ at first treatment, however, at the second treatment, CL were expected to be 6 to 12 days old and synchronous luteolysis should occur. Each ewe assigned to low progesterone received a progesterone-containing insert (Controlled Internal Drug Releasing Device [CIDR] containing $0.3 \mathrm{mg}$ of progesterone) on day 4 after estrus and was given $\mathrm{PGF}_{2} \mathrm{\alpha}$ on $\mathrm{d} 6$ (as in the synchronization protocol) to regress the $\mathrm{CL}$ and remove endogenous progesterone. These ewes were expected to have low circulating concentrations of progesterone. Ewes in the high progesterone group received a CIDR on day 4 to provide additional progesterone to that produced by the CL. In each group, the CIDR was removed on day 14. Untreated ewes were used as controls, and were expected to have medium circulating concentrations of progesterone.

Breeding soundness examination, ram introduction and observation for estrus

A breeding soundness examination (testicular size, sperm concentration and motility; Salamon, 1976) was performed on six Barbados Blackbelly rams, each of which was found to be in breeding condition. On day 7 after estrus, the rams were raddled and allotted to six pens, each of which contained five or six ewes from each of the low, medium, and high treatment groups. A maximum ewe-to-ram ratio of $17: 1$ was 
maintained. Ewes were observed on days 7 through 21 at 6 am and 6 pm for raddle marks. Time and date of observed estrus were recorded to determine the interval from CIDR removal to post-treatment estrus (marked by a ram; $0.5 \mathrm{~d}$ increments). After each observation for estrus, briskets of the rams were repainted with different colors to distinguish ewes that subsequently came into estrus and to ensure that raddle marks were visible.

Observations of follicular development

Follicular development and ovulation were observed by transrectal ultrasonography using an Aloka 500 SSD (Corometrics) equipped with a $7.5 \mathrm{MHz}$ lineararray transducer, as described by Schrick et al. (1993). Ultrasonographic observations were done by two operators in replicate 1, but by only one of them in replicate 2 . Ovaries of 10 ewes per treatment in replicate 1 and of 8 ewes per treatment in replicate 2 were scanned daily from day 5 through subsequent estrus and ovulation. Ovarian follicular diameters were measured in three categories; small (2 to $3 \mathrm{~mm}$ ), medium ( 4 to $5 \mathrm{~mm})$, and large $(\geq 6 \mathrm{~mm})$, and their relative positions and those of CL were recorded on an ovarian map. This allowed determination of the sequential appearance, growth, atresia and disappearance (ovulation) of follicles. Data recorded included the day of emergence of each ovulatory follicle, the numbers of small, medium and large follicles, and maximum size of each ovulatory follicle prior to ovulation. Growth rates of follicles were determined by retrospective comparisons of the follicle sizes recorded up to the point of plateau in diameter or ovulation. The interval from day of appearance (at 2 or 3 $\mathrm{mm}$ ) to disappearance was termed the life span of the follicle. Follicles that were first detected at $4 \mathrm{~mm}$ were recorded as $3 \mathrm{~mm}$ one day earlier, because average growth rate 
approximates $1 \mathrm{~mm}$ per day (Schrick et al., 1993). After estrus, follicles $\geq 4 \mathrm{~mm}$ were recorded as ovulated if not observed on the ovary at the subsequent scanning (Schrick et al., 1993). The interval from CIDR removal to ovulation was measured from these observations. Ovulation rate was confirmed by the number of $\mathrm{CL}$ observed by ultrasonography seven days after ovulation.

Lambing dates and numbers of lambs born were recorded. Conception rate was determined by ewes lambing as a percentage of ewes in estrus. Pregnancy rate was measured as the percentage of ewes treated that lambed. Prolificacy was expressed as the number of lambs born per ewe that lambed.

Sampling and assay for progesterone

To determine circulating concentrations of progesterone, $10 \mathrm{~mL}$ of blood was collected by jugular venipuncture at 5:30 am, prior to transrectal ultrasonography, from a subset of eight ewes per treatment in each replicate on selected days. Collections were made at pre-treatment estrus (day 0 ), and on days 4 (CIDR insertion), $6\left(\mathrm{PGF}_{2} \alpha\right)$, $8,11,12,14$ (CIDR removal), and 16 and post-treatment estrus. At each bleeding, the sample was collected into a heparinized vial and centrifuged immediately. The plasma was transferred to glass ampules and stored at $-20 \mathrm{C}$ until assayed for progesterone. Estrus was confirmed by low concentrations of progesterone, and patterns of concentrations during treatment were used to validate treatments.

The DSL-10-3900 ACTIVE ${ }^{\circledR}$ Progesterone Enzyme Immunoassay (EIA) kit, which was developed for measurement of progesterone in human beings, was used according to instructions by the manufacturer (Diagnostic Systems Laboratories, Inc., Corporate Headquarters, 445 Medical Center Blvd. Webster, Texas 77598-4217. USA) for assay 
of progesterone. The sensitivity of the assay was $0.13 \mathrm{ng} / \mathrm{mL}$. In this study, the EIA values (mean $8.7 \mathrm{ng} / \mathrm{ml}$ ) were similar to the range obtained using ELISA (Godfrey et al., 1997; OVUCHECK, Cambridge Veterinary Sciences Ltd) and RIA (Van Cleeff et al. 1998). However, the reagents in the kit were not tested for cross reactivity with lipids or other components of sheep plasma, and the samples were tested without extraction.

As expected, concentrations of progesterone increased after insertion of the CIDRS on day 4 (Figure 1). In ewes treated with $\mathrm{PGF}_{2} \mathrm{\alpha}$ on day 6 (low progesterone group), concentrations of progesterone were about $1 \mathrm{ng} / \mathrm{ml}$ lower than in the high group from days 6 through 14, but remained above the ewes expected to have medium progesterone until day 12. Higher concentrations of progesterone were maintained in the high compared to the medium and low groups until day 14 when the CIDRS were removed; then progesterone declined precipitously in each group.

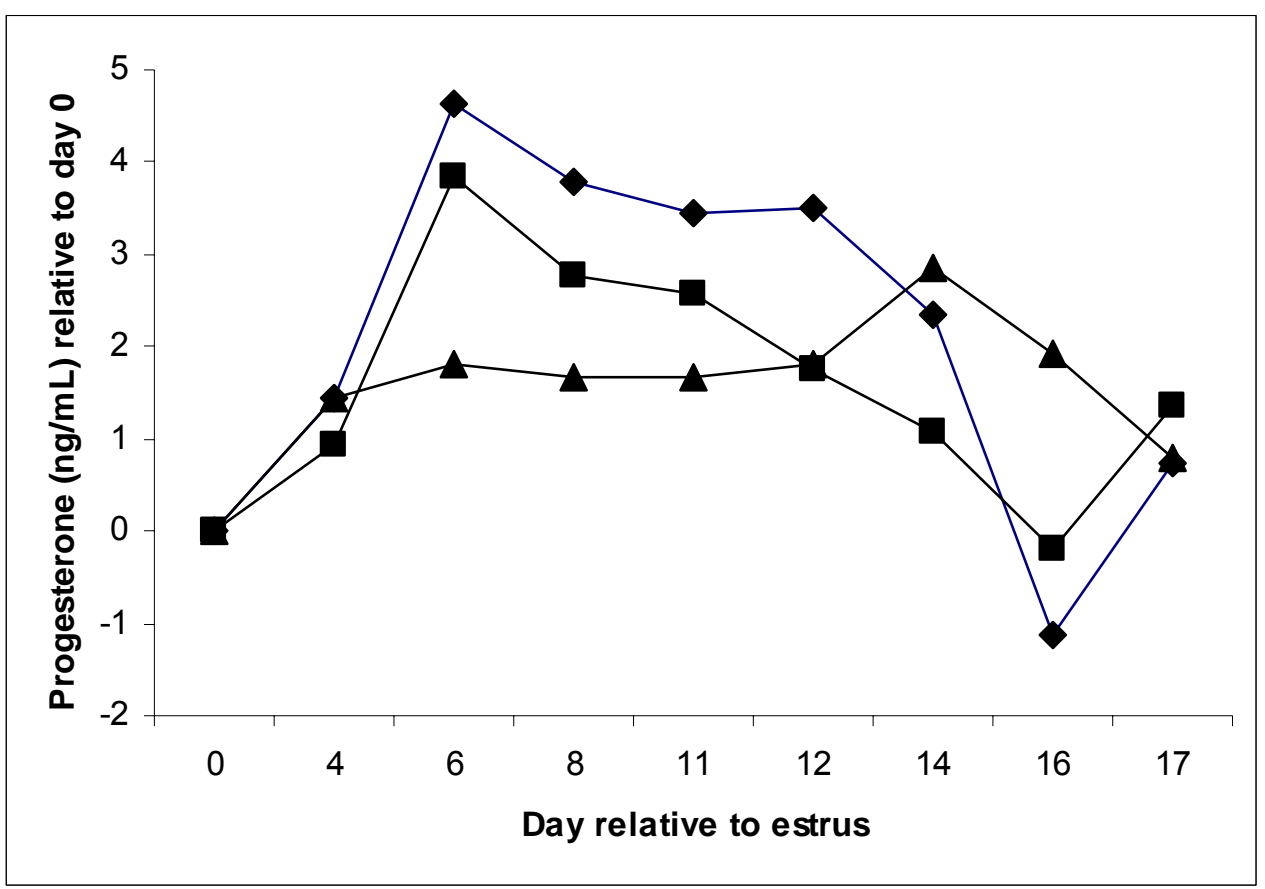

Figure 1 Concentrations of progesterone $(\mathrm{ng} / \mathrm{mL})$ relative to day 0 in ewes treated to 
have high ( $\bullet$ ), medium ( $\mathbf{\square})$ or low $(\boldsymbol{\Delta})$ progesterone.

\section{$\underline{\text { Statistical Analysis }}$}

Significant differences were set at $p<0.05$ and $p<0.01$. The intervals from CIDR removal to estrus and ovulation and the growth rate of follicles in the final and penultimate waves were analyzed by GENMOD procedure. A square root transformation on counts of follicles was performed. Differences in the average diameter of all ovulatory follicles and growth rate of follicles with both final and penultimate waves combined were compared as least squares means, by analysis of variance with PROCMIXED GLM with a square root transformation, using version 8.1 of Statistical Analysis Systems Institute (2002). The number of follicles per day with ewe as a repeated autoregressive measure and number of ovulatory follicles were compared by GENMOD using Poisson regression. The data were normalized to day 0 for the scanned period and the effects of treatment on the numbers of small (2 to $3 \mathrm{~mm}$ ), medium (4 to $5 \mathrm{~mm}$ ) and large ( $\geq 6 \mathrm{~mm}$ ) follicles were compared, with ewe nested within treatment and day and day by treatment interaction within ewe. Conception rate and pregnancy rate were examined by Chi-square. Lambs born per CL, per ewe lambing (prolificacy), and partial embryonic loss were compared by GENMOD procedure using logistic regression. The number of follicles and the interval (days) that each follicle was observed in the final and penultimate waves, and lambing patterns were analyzed by PROCMIXED GLM. Correlation coefficients was calculated to examine the relationship between follicles that disappeared and $\mathrm{CL}$ formed. 


\section{Results}

$\underline{\text { Interval to estrus }}$

Time to estrus was determined as the interval from removal of the CIDRS until the ewes were marked by raddled rams. The percentages of ewes marked were 94.6, 91.0 and 83.9 for low, medium, and high progesterone, respectively. Days to estrus were fewer for ewes treated to have low $(1.5 \pm 0.1)$ than medium $(2.2 \pm 0.2 ; p<0.0001)$

or high $(1.9 \pm 0.2 ; p<0.01)$ concentrations of progesterone. The interval (days) from CIDR removal to ovulation (Table 1) was less for ewes with low $(2.0 \pm 0.3)$ than with high $(3.2 \pm 0.2 ; p<0.05)$ progesterone and tended to be less than for ewes with medium $(2.9 \pm 0.6 ; p<0.09)$ progesterone. 
Table 1. Occurrence of estrus and ovulation rates in Barbados Blackbelly ewes in response to low, medium or high circulating concentrations of progesterone during the previous cycle.

\begin{tabular}{lccc}
\hline \multicolumn{1}{c}{ Variable } & Low & Medium & High \\
\hline & & & \\
\hline Number of ewes & 56 & 56 & 56 \\
Ewes marked by rams (\%) & $53(94.6)$ & $51(91.0)$ & $47(83.9)$ \\
Interval from CIDR removal to estrus ${ }^{\text {a }}$ & $1.5 \pm 0.1$ & $2.2 \pm 0.2$ & $1.9 \pm 0.1$ \\
Number of ewes observed for ovulation ${ }^{\text {b }}$ & 18 & 18 & 18 \\
Ewes observed to ovulate \% & 88.8 & 83.3 & 83.3 \\
Interval from CIDR removal to ovulation $^{c}$ & $2.0 \pm 0.3$ & $2.9 \pm 0.6$ & $3.2 \pm 0.2$ \\
\hline
\end{tabular}
a) Low vs High, $p<0.01$; Low vs Medium ( $p<0.0001)$.
b) Time of ovulation was estimated by disappearance of follicles at twice daily observations by transrectal ultrasonography.
c) Low vs High, $p<0.05$; Low vs Medium $(p<0.09)$. 


\section{Follicle numbers, growth, ovulation rates and days to emergence}

The numbers of large ( $\geq 6 \mathrm{~mm}$ in diameter) and medium ( 4 to $5 \mathrm{~mm}$ ) follicles present each day during days 6 to 14 varied with day and day by treatment interaction $(p<0.0001)$, but number of small $(2$ to $3 \mathrm{~mm}$ ) follicles did not differ (Figure 2$)$. The total number of follicles on the ovary varied with day by treatment interaction $(p<0.001$; figure 2). Ewes with low progesterone had fewer $(p<0.01)$ medium and large follicles prior to ovulation than ewes with high and medium concentrations of progesterone (Figure 3). One ewe with medium concentrations of progesterone in replicate 1, showed a cystic follicle prior to treatment, which remained on the ovary throughout treatment and did not ovulate, although the ewe came into estrus and ovulated two follicles on the opposite ovary. The disappearing follicles in the penultimate wave grew more slowly ( $0.7 \mathrm{~mm} /$ day) when compared to those of the final wave $(0.9, \mathrm{~mm} / \mathrm{d})$. The ewes with high $(0.7 ; \mathrm{mm} / \mathrm{d})$, medium $(0.8)$ and low $(0.6)$ concentrations of progesterone did not differ in mean follicular growth rate in the final or penultimate wave. The effect of treatment (expected concentration of progesterone) on ovulation rate was linear ( $p<$ $0.01)$, regardless of whether ovulation rate was estimated by disappearance of follicles at estrus or number of $C L$ on day 7 after ovulation. The number of follicles ( $\geq 4 \mathrm{~mm}$ ) that disappeared in relation to estrus increased linearly $(p<0.02)$ with decreasing concentrations of progesterone. Disappearance of follicles was apparently an overestimate of ovulation rate. Ewes with low progesterone $(2.6 \pm 0.2)$ had a higher number of $C L$ than ewes with medium progesterone $(1.9 \pm 0.2 ; p<0.05)$ or high $(1.7 \pm$ $0.1 ; p<0.005)$, which did not differ. The number of follicles that disappeared was correlated to the number of $C L$ formed $(r=0.53 ; p<0.0001)$.

Last diameters of ovulatory follicles did not differ among ewes on low $(4.9 \pm 0.5)$, medium $(4.6 \pm 0.7)$ or high $(4.9 \pm 0.5)$ concentrations of progesterone. The mean interval (days) from emergence at 2 or $3 \mathrm{~mm}$ to ovulation in the final or penultimate follicular wave did not differ (Table 2). The mean number of days that ovulatory follicles were present prior to ovulation was $5.7 \pm 0.6,7.6 \pm 0.6$ and $8.1 \pm 0.2$ for ewes with high, medium and low concentrations of progesterone, respectively. The mean numbers of days from emergence to ovulation for ovulatory follicles were $9.0 \pm 0.2$ and $5.0 \pm 0.2$ for the penultimate and final waves, respectively. 

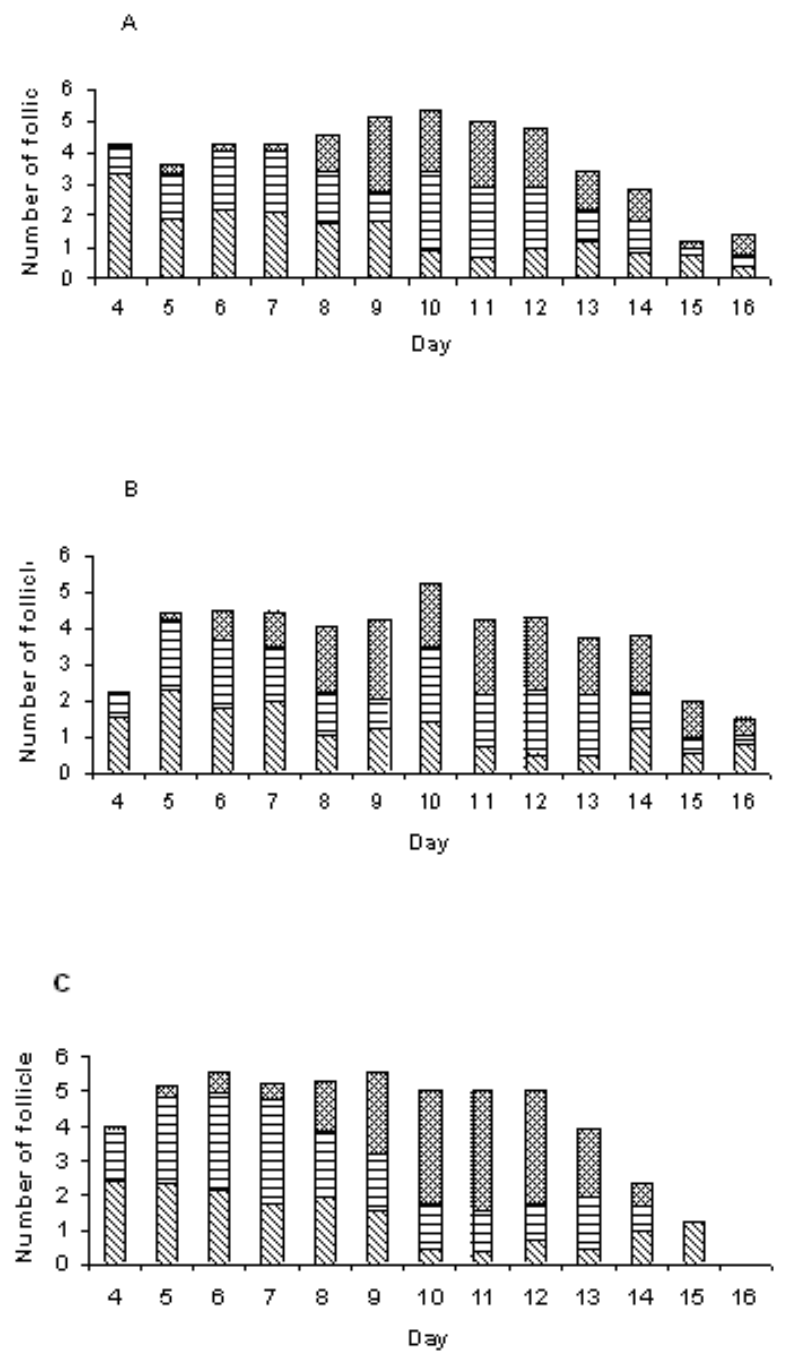

Figure 2. Numbers of total follicles (height of each bar at each day) and numbers in each size class (Diagonal-2 and $3 \mathrm{~mm}$; horizontal-4 and $5 \mathrm{~mm}$; and cross hatched $\geq 6$ $\mathrm{mm}$ ) on days 4 through 16 in ewes on high $(\mathrm{A})$, medium $(\mathrm{B})$, or low $(\mathrm{C})$ progesterone summed over both ovaries. 


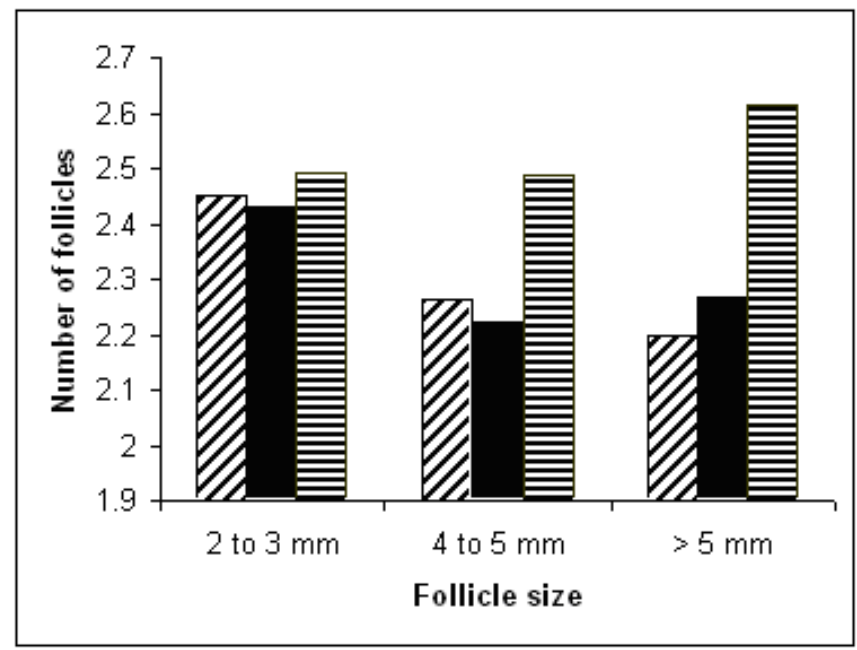

Figure 3. Numbers of follicles in each size class on the day prior to ovulation (Diagonalhigh; solid-medium; horizontal-low). Numbers of medium and large follicles for the low progesterone group were greater than in the high and medium groups $(p<0.01)$. 


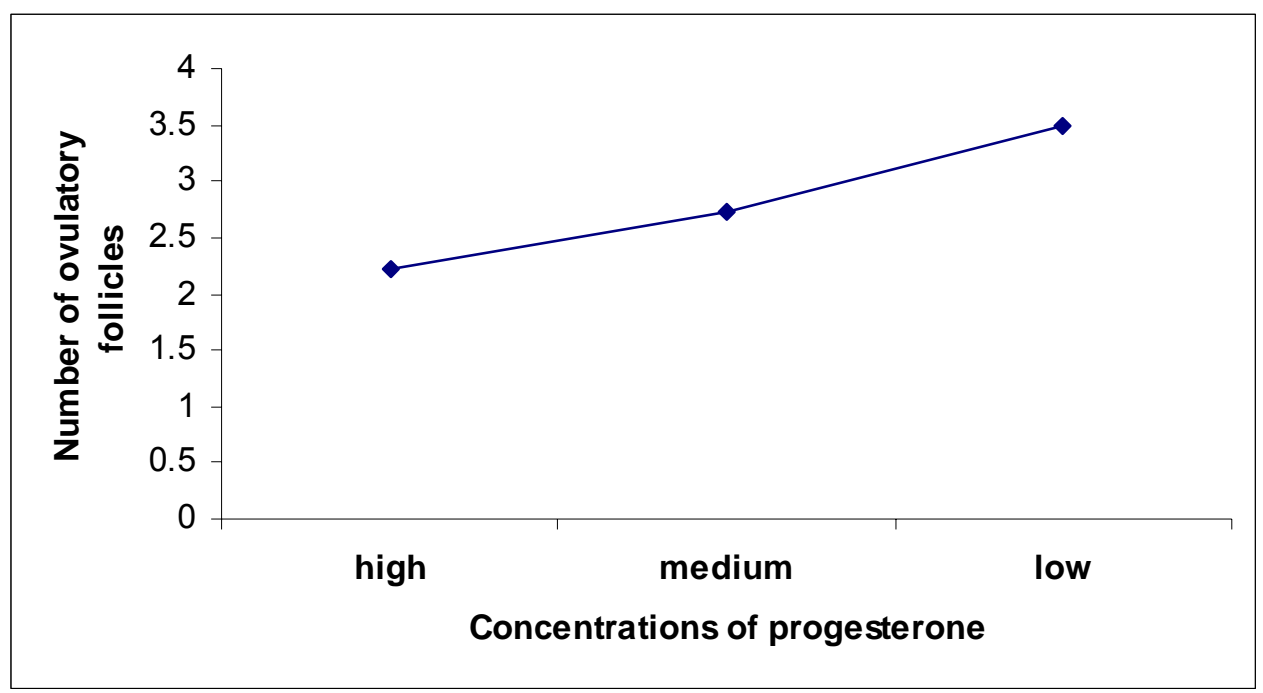

Figure 4. The number of disappearing follicles in ewes with high, medium or low concentrations of progesterone. The number of disappearing follicles increased linearly with decreasing concentrations of progesterone $(p<0.02)$. 


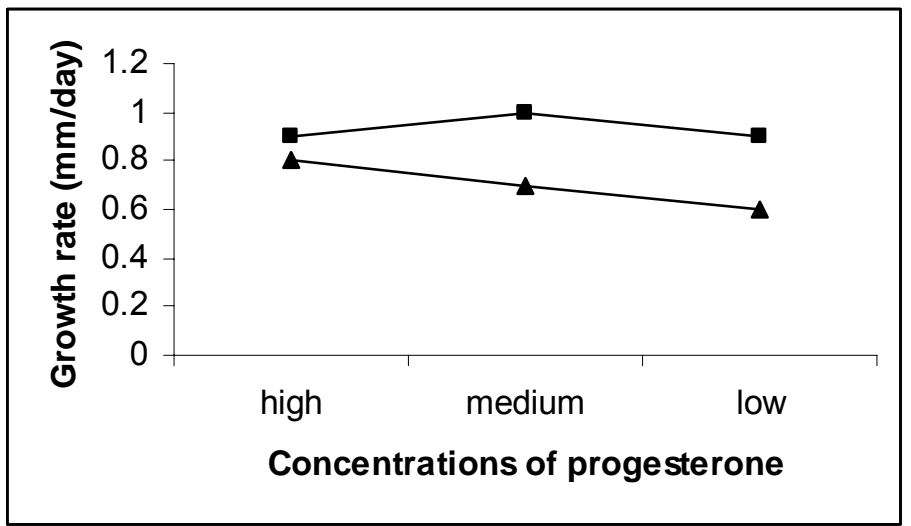

Figure 5 Mean growth rates of disappearing follicles in the final $(\mathbf{\Delta})$ or penultimate $(\boldsymbol{\square})$ waves in low, medium and high progesterone groups. The follicular growth rates in the final or penultimate waves did not differ among treatment groups. 
Table 2. Time from emergence to disappearance of presumed ovulatory follicles from the final or penultimate waves.

\begin{tabular}{|c|c|c|c|c|}
\hline & \multicolumn{3}{|c|}{ Concentration of progesterone } & \multirow[b]{2}{*}{ All Groups } \\
\hline & High & Medium & Low & \\
\hline Time from emergence to ovulation: & $n=15$ & $\mathrm{n}=15$ & $\mathrm{n}=16$ & \\
\hline \multicolumn{5}{|l|}{ Final follicular wave } \\
\hline Total number of follicles observed & 21 & 19 & 13 & 53 \\
\hline Interval (days) & $4.6 \pm 0.5^{a}$ & $5.2 \pm 0.3^{a}$ & $5.5 \pm 0.3^{a}$ & $5.0 \pm 0.3^{c}$ \\
\hline \multicolumn{5}{|l|}{ Penultimate follicular wave } \\
\hline Total number of follicles observed: & 12 & 22 & 43 & 77 \\
\hline Interval (days) & $8.2 \pm 0.3^{a}$ & $9.0 \pm 0.3^{a}$ & $9.22 \pm 0.2^{a}$ & $9.0 \pm 0.2^{d}$ \\
\hline \multicolumn{5}{|l|}{ Both waves } \\
\hline Total number of follicles observed: & 33 & 41 & 56 & 130 \\
\hline Interval (days) & $5.7 \pm 0.6^{a}$ & $7.6 \pm 0.6^{b}$ & $8.1 \pm 0.2^{b}$ & $7.2 \pm 0.4$ \\
\hline
\end{tabular}

Means in the same row with different superscripts $(a, b$,$) differed among treatments (p<0.05$; Duncan's multiple range test)

Means of waves differed ( $p<0.05$; designated by superscripts $c$ and $d)$. 
Conception and pregnancy rates

Conception and pregnancy rates averaged 75.8 and $73.8 \%$, respectively, and did not differ among treatment groups. Partial embryonic or fetal loss (CL not represented by lambs born) was greater $(1.3 \pm 0.2 ; p<0.006)$ for ewes with low concentrations of progesterone than for either ewes on medium $(0.9 \pm 0.2)$ or high $(0.8 \pm 0.2)$ concentrations of progesterone.

Lambs born in relation to ovulation rate; prolificacy and lambing rate per ewe treated

Number of $\mathrm{CL}$ (figure 6A) increased linearly $(p<0.001)$ with decreasing concentrations of progesterone. Births per CL decreased linearly $(p<0.001)$ with decreasing concentrations of progesterone (figure 6B). As a result, the greater ovulation rates (Figure $6 \mathrm{~A}$ ) observed with lower concentrations of progesterone did not produce a corresponding increase in the number of lambs born per ewe lambing (Figure 6C). Lambs born per ewe lambing (prolificacy) averaged $2.00 \pm 0.14,1.86 \pm 0.11$ and $1.90 \pm$ 0.12 for low, medium and high progesterone, respectively, which did not differ. Lambs born per ewe treated (Lambing rate) did not differ among ewes on low (1.5 \pm 0.2 ), medium $(1.5 \pm 0.1)$ or high $(1.3 \pm 0.1)$ concentrations of progesterone. Quintuplets were born to one ewe with high and one ewe with low concentrations of progesterone and quadruplets were born to one ewe with medium concentrations of progesterone. 


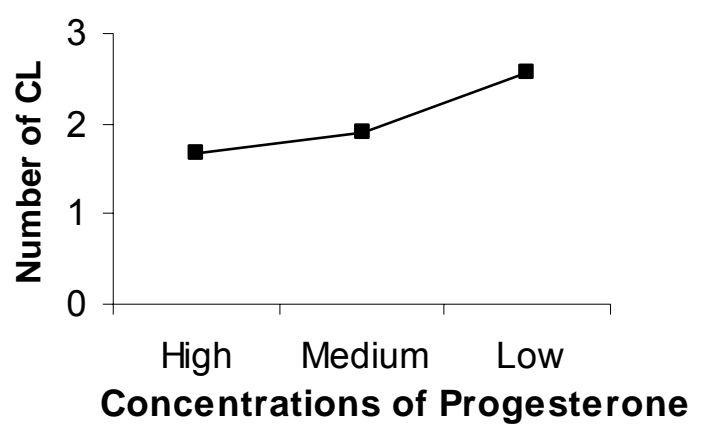

6A

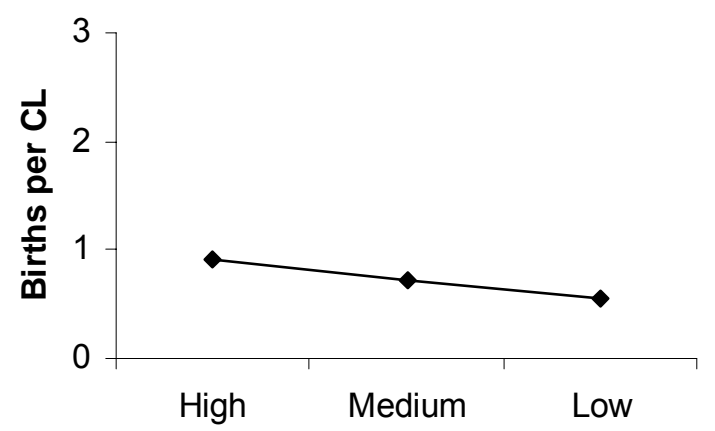

6B

Concentrations of progesterone

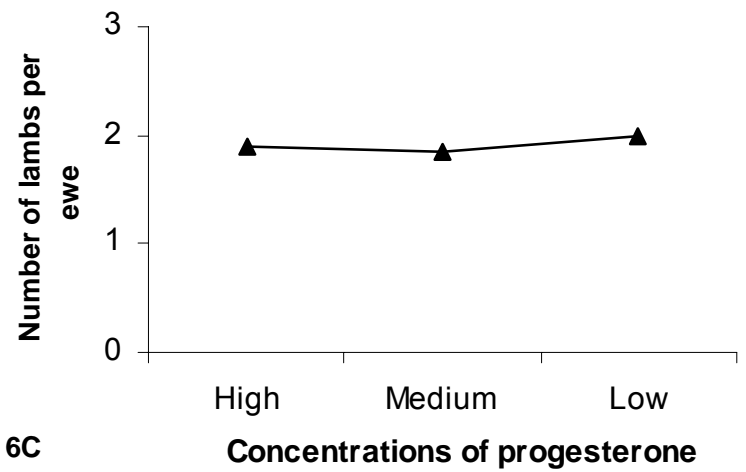

Figure 6 A Means ( \pm SEM) number of $C L$ in ewes that lambed to first service with high $(n=39)$, medium $(n=44)$, or low $(n=41)$ concentrations of progesterone. Treatment effect was linear $(p<0.001)$. B. The treatment effect on lambs born per $C L$ was linear $(p$ $<0.01)$. C. Number of lambs born per ewe lambing (prolificacy) did not differ. 


\section{Lambing pattern}

The mean intervals from estrus to lambing were $148 \pm 0.4,147.7 \pm 0.5$, and $147.5 \pm 0.4$ days for ewes on high, medium and low concentrations of progesterone, respectively, and did not differ (Figure 7).

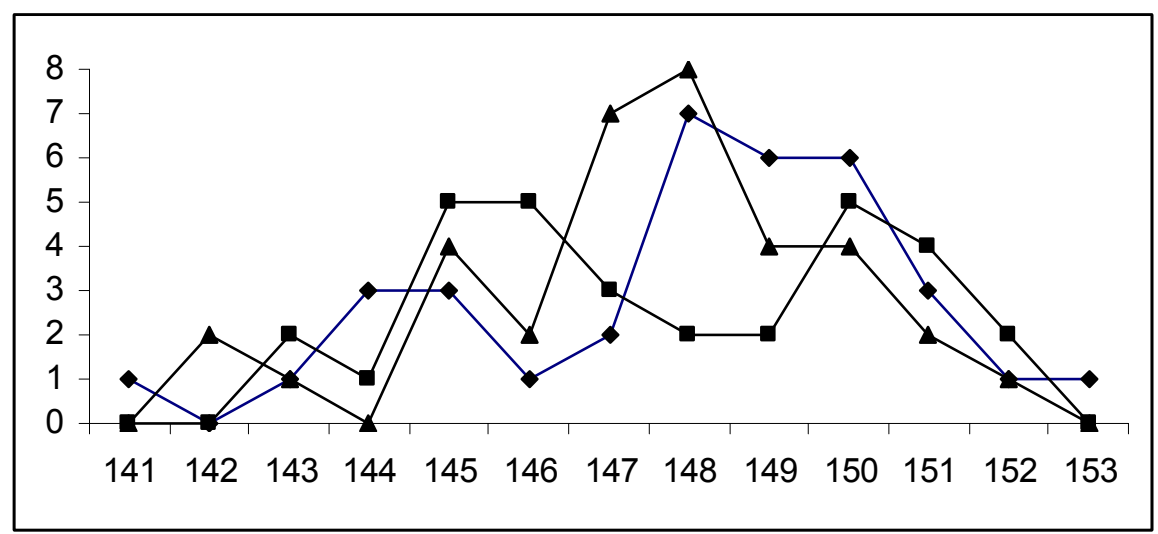

Figure 7 Lambing patterns of ewes with high ( $\bullet)$, medium ( $\mathbf{\square})$ or low $(\mathbf{\Lambda})$ progesterone concentrations of progesterone.

\section{Discussion}

Ovulation rate, pregnancy rate and prolificacy. Ovulation rate, as represented by either the number of follicles that disappeared or the number of $C L$ observed on day 7 after estrus, increased linearly as the expected concentration of progesterone decreased. The increase in ovulation rate in ewes with lower concentrations of progesterone was due to retention and ovulation of more follicles from the penultimate wave of follicular development. This finding is in agreement with Johnson et al. (1996) and Bartlewski et al. (1999; 2003), who reported that follicles of varying ages, or originating from both the penultimate and final follicular waves, ovulated in the cycling ewe. Additionally, it extends to prolific ewes the finding by Bartlewski et al. (2003) in non-prolific ewes that exposure to low concentrations of progestogens during the luteal phase can increase 
ovulation rate. In contrast, low concentrations of progesterone prolonged the growth phase of the dominant follicle, which inhibited other follicles from growing in heifers (Adams et al., 1992). Furthermore, multiple ovulations in cattle were attributed to the effect of co-dominance, which occurs during the first follicular wave when two follicles are maintained on the ovary. This phenomenon is a result of low concentrations of progesterone, which permits frequent pulses of $\mathrm{LH}$; greater concentrations of estradiol are increased due to the increased number of follicles (Kulick et al., 2001). This mechanism might occur early in the estrous cycle in the ewe, but unlike the cow, other follicles can be recruited while the other largest follicles are present on the ovary of the ewe throughout the luteal phase.

The number of follicles that disappeared and was presumed to have ovulated was an overestimate of the number of $C L$ observed on day 7 after estrus, which was used as a confirming and final measure of ovulation rate. Similarly, Bartlewski et al. (2003) observed that not all follicles that disappeared at estrus formed CL. The accuracy of observation of disappearance of follicles as a measure of ovulation rate might have been reduced, because some follicles $\geq 4 \mathrm{~mm}$ did not ovulate but regressed in size and might have been assumed to be new 2 or $3 \mathrm{~mm}$ follicles. Alternatively, some ovulated follicles might not form a CL. In earlier work, Murdoch et al. (1983) observed that ewes injected with LH or FSH on d 15 ovulated, but were unable to develop sufficient luteal function. They suggested that the pre-ovulatory follicle was forced to ovulate prematurely and lacked gonadotropin receptors on follicular cells, which is measure of follicular maturity and the inherent ability to undergo luteinization to form a $\mathrm{CL}$. When follicular synthesis of estrogen was reduced by treatment with an aromatase inhibitor and follicles were ovulated/luteinized with an injection of hCG (Benoit et al., 1992), estrus did not occur and the onset of luteal function was delayed. However, ewes showed estrus naturally after withdrawal of progesterone in the present study, and pregnancy rates were in the normal range, so function of $C L$ that were formed must have been adequate.

Pregnancy rates did not differ with concentrations of progesterone in the present study. Evans et al. (2001) found that lower dosages of progestogen had no deleterious effects on embryo quality or fertility and concluded that aged follicles in sheep were less critical than in cattle. In contrast, lower luteal phase concentrations of progesterone or 
progestogens and the ovulation of older follicles was associated with reduced conception and pregnancy rates in ewes (Johnson et al., 1996; Ungerfeld and Rubianes 1999; Viñoles et al., 2001). Similarly, cows with low concentrations of progesterone during the luteal phase ovulated an older follicle. and had decreased pregnancy rate (Cooperative Regional Research Project NE-161, 1996) due to death of embryos during the 2 to 16 cell stage (Ahmad et al., 1995; Oussaid et al. 1999).

The number of lambs born per CL observed on day seven after estrus declined linearly with decreasing concentrations of progesterone during the luteal phase preceding ovulation. As a result, despite the linear increase in the ovulation rate with decreasing concentrations of progesterone, there was no net improvement in prolificacy of the ewe. Because pregnancy rates did not differ with concentrations of progesterone in the present study, decreasing progesterone resulted in an increase in partial rather than total pregnancy loss. The greater reproductive wastage in ewes with lower luteal phase concentrations of progesterone, which ovulated more follicles from the penultimate wave, might have been due to reduced fertilization rate, greater embryonic death, greater fetal death, or a combination of those factors.

Fertilization rates were reduced at the start of the breeding season (Hulet et al., 1956) or the late breeding season, as a possible consequence of seasonal shifts in LH secretion and (or) associated effects on follicular function (Mitchell et al., 2002). However, fertilization loss can be complete (Hulet et al., 1956) or partial (Wilkins, 1997; Kleemann et al., 2005). Early embryonic death losses were greater in early season breeding and accounted for the complete loss of the pregnancy (Hulet et al., 1956). Negative relationships between ovulation rate and embryonic mortality in sheep have been reported previously (Meyer, 1985, cited by Dixon 2003; Dixon, 2003; Knights et al., 2003). Losses might well be expected to occur in the early embryonic period. Older ovulatory follicles originating from the penultimate wave may not be as healthy and may be a causative factor of the higher reproductive wastage.

However, uterine capacity might have influenced litter size indirectly through the inability to sustain additional embryos (Meyer, 1985, cited by Dixon, 2003). In addition, complete embryonic loss was greater in ewes with lower progesterone at days 26 to 30 of gestation (Dixon, 2003). However, partial embryonic loss of pregnancy was not related to concentrations of progesterone at that time. In a later study, Dixon (2003) 
observed that ewes with a higher number of embryos were more prone to have complete or partial embryonic loss. The majority of ewes lost one embryo and $22 \%$ of embryos were lost before term. Three to four percent of embryos present at day 25 subsequently were lost during each 20-day interval of pregnancy. In contrast, in dairy cattle, the entire pregnancy might be lost between days 30 and 60 in cows that had twin ovulations (Starbuck et al., 2004). Interestingly, the occurrence of double ovulations was minimally different between cows and heifers, yet twinning occurred more frequently in cows than in heifers. In previous work, Vandeplassche et al. (1979) postulated that uterine capacity was the limiting factor in heifers.

Mechanism of effects of low progesterone on follicles. The mechanism through which low luteal phase concentrations of progesterone might alter the pattern of follicular development and increase ovulation rate in the ewe is not clear. In cows, lower progestogen led to increased pulse frequency of $\mathrm{LH}$, maintenance of dominant follicles and greater secretion of estradiol (Stock and Fortune, 1993; Kinder at al., 1996). Taft et al. (1996) found that treatment of cows with frequent injections of bovine LH during normal luteal phases maintained the largest (dominant) follicle and suppressed recruitment of other follicles. This mechanism might not apply to the ewe, in which follicles are recruited despite the presence of other large follicles (Duggavathi et al., 2003). However, low concentrations of progesterone reduced atresia of recruited follicles in ewes (Turnbull et al., 1978; Avdi et al., 1997; Reynaud et al., 1999; Mandiki et al., 2000). Follicles in the penultimate wave might have been protected from atresia because of greater frequency of secretion of pulses of $\mathrm{LH}$ in ewes on lower concentrations of progesterone, as observed by Johnson et al. (1996) and Van Cleeff et al. (1998).

Growth rate of follicles was slower in the penultimate than in the final wave. As a result, average maximum diameter of the ovulatory follicles did not differ among treatment groups. In contrast, Johnson et al. (1996) observed that the diameter of the ovulatory follicle was greater in ewes that had low concentrations of progesterone. Concentrations of progesterone in the "low" group were below both the "medium" and "high" groups for only the last 2 to 3 days of the luteal phase of the estrous cycle before breeding in the present study. Johnson et al. (1996) treated with lower concentrations of progesterone (and thus ewes were subjected to a greater frequency of LH pulses) for a 
longer period of time, stimulating a greater increase in diameter of follicles. Thus, rate of growth of follicles in the penultimate wave might have been limited by relatively greater concentrations of progesterone during the mid- to late luteal phase of the cycle. In comparison, most growth of ovulatory follicles from the ultimate wave occurred during the very late luteal and follicular phases of the estrous cycle, when progesterone concentrations were waning and pulsatile secretion of LH was increased.

The average ovulatory follicle was retained on the ovary for about one day longer in ewes with low concentrations of progesterone than in ewes with high or medium concentrations of progesterone. Follicles from the penultimate wave were an average of three days older at ovulation than follicles from the ultimate wave. Similarly, the lifespan of the largest follicles in the penultimate wave (Bartlewski et al., 1999) or that arose earlier (Johnson et al. 1996) was increased, which allowed them to ovulate with follicles from the final wave.

Other considerations. Rams were introduced to the ewes in this study seven days before withdrawal of progesterone or regression of corpora lutea. Based upon a study by Evans et al. (2004), exposure to rams for three days before progestogen withdrawal might have been expected to limit fertility or prolificacy. They found 14 and 9 percentage point reductions in ewes lambing to first service in two trials and 0.23 fewer lambs born per ewe lambing in one of those trials, which they attributed to increased LH pulse frequency in response to ram introduction during treatment with progestogen. However, their results might have been influenced in part by the fact that they delayed introduction of intact rams for breeding until 48 hours after sponge withdrawal. In the present study, the same intact rams remained with the ewes throughout and overall pregnancy rate was a quite acceptable $74 \%$, similar to that reported for hair sheep in the tropics (74\%; Godfrey et al., 1997) and greater than that observed in ewes treated with intravaginal inserts (CIDRS) in the breeding season (57\%; Rhodes and Nathanielsz,1988).

\section{Conclusions}

In summary, the removal of endogenous progesterone and the use of intravaginal inserts induced low circulating concentrations of progesterone, which increased the ovulation rate through more follicles being maintained from the penultimate wave, but did not result in an increased litter size. The increase in ovulation rate might be due to greater LH pulse frequency, which regulates follicular and oocyte 
maturation. Older oocytes, ovulated from follicles of the penultimate wave, might have been incapable of either fertilization or embryonic development, the latter being more likely based upon the literature in the cow. Furthermore, uterine capacity might have been a factor that limited litter size.

\section{Literature cited:}

Acritopoulou, S., and W. Haresign. 1980. Response of ewes to a single injection of an analogue of PGF-2 alpha given at different stages of the oestrous cycle. J. Reprod. Fertil. 58: 219-221.

Acritopoulou, S., W. Haresign, J. P. Foster, and G. E. Lamming. 1977. Plasma progesterone and lh concentrations in ewes after injection of an analogue of prostaglandin f-2alpha. J. Reprod. Fertil. 49: 337-340.

Adams, G. P., R. L. Matteri, and O. J. Ginther. 1992. Effect of progesterone on ovarian follicles, emergence of follicular waves and circulating follicle-stimulating hormone in heifers. J. Reprod. Fertil. 96: 627-640.

Adams, T. E., J. F. Quirke, J. P. Hanrahan, B. M. Adams, and J. G. Watson. 1988. Gonadotrophin secretion during the periovulatory period in galway and finnish landrace ewes and finnish landrace ewes selected for high ovulation rate. J. Reprod. Fertil. 83: 575-584.

Ahmad, N., F. N. Schrick, R. L. Butcher, and E. K. Inskeep. 1995. Effect of persistent follicles on early embryonic losses in beef cows. Biol. Reprod. 52: 1129-1135.

Albihn A, H. Gustafsson, M. Hurst and H. Rodriguez-Martinez. 1991. Embryonic ability to prolong the interoestrous interval in virgin and repeat breeder heifers. Anim. Reprod. Sci. 26: 193-210.

Alliston, C.W., and L. C. Ulberg. 1961. Early pregnancy loss in sheep at ambient temperatures of 70 and 90 as determined by embryo transfer. J. Anim. Sci. 20: 608-612.

Allison, A. J., and T. J. Robinson. 1970. The effect of dose level of intravaginal progestagen on sperm transport, fertilization and lambing in the cyclic merino ewe. J. Reprod. Fertil. 22: 515-531.

Allison, A. J., and T. J. Robinson. 1972. The recovery of spermatozoa from the reproductive tract of the spayed ewe treated with progesterone and oestrogen. J. Reprod. Fertil. 31: 215-224.

Andersen C.Y., L. G. Westergaard and M. van Wely. 2004. FSH isoform composition of commercial gonadotropin preparations: a neglected aspect? A. Reprod. Biomed Online. 2: 231-236.

Arimura, A., and A. V. Schally. 1971. Augmentation of pituitary responsiveness to threleasing hormone (lh-rh) by estrogen. Proc Soc Exp Biol Med 136: 290-293.

Asdell, S. A., J. de Alba and J. S. Roberts. 1949. Studies on the oestrus cycle of dairy cattle: cycle length, size of corpus luteum and endometrial changes. Cornell Vet. 39: 389.

Atkinson, S., and P. Williamson. 1985. Ram-induced growth of ovarian follicles and gonadotrophin inhibition in anoestrous ewes. J. Reprod. Fertil. 73: 185-189.

Avdi, M., P. Chemineau, and M. A. Driancourt. 1997. Alterations in follicular maturation associated with within-breed variation in ovulation rate in chios sheep. Anim. Reprod. Sci. 46: 223-235. 
Baird, D. T. 1978. Pulsatile secretion of LH and ovarian estradiol during the follicular phase of the sheep estrous cycle. Biol. Reprod. 18: 359-364.

Baird, D.T. and R. J. Scaramuzzi. 1975. Prostaglandin F2 alpha and luteal regression in the ewe: comparison with 16 aryloxyprostaglandin (I.c.i. 80, 996). Ann. Biol. Anim. Biochem. Biophys. 15: 161-174.

Baird, D. T., and R. J. Scaramuzzi. 1976. Changes in the secretion of ovarian steroid and pituitary luteinizing hormone in the peri-ovulatory period in the ewe: The effect of progesterone. J. Endocrinol. 70: 237-245.

Bartlewski, P. M., A. P. Beard and N. C. Rawlings. 1999. Ovarian antral follicular dynamics and their relationships with endocrine variables throughout the oestrous cycle in breeds of sheep differing in prolificacy. J. Reprod. Fertil. 115: 111-124.

Bartlewski, P. M., A. P. Beard, and N. C. Rawlings. 1999. An ultrasonographic study of luteal function in breeds of sheep with different ovulation rates. Theriogenology 52: $115-130$.

Bartlewski, P. M., R. Duggavathi, J. Aravindakshan, D. M. W. Barrett, S. J. Cook and N. Rawlings. 2003. Effects of a 6-day treatment with medroxyprogesterone acetate after prostaglandin $\mathrm{f} 2$ alpha-induced luteolysis at midcycle on antral follicular development and ovulation rate in nonprolific western white-faced ewes. Biol. Reprod. 68: 1403-1412.

Benoit, A. M., E. K. Inskeep, and R. A. Dailey. 1992. Effect of a nonsteroidal aromatase inhibitor on in vitro and in vivo secretion of estradiol and on the estrous cycle in ewes. Domest. Anim. Endocrinol. 9: 313-327.

Blair, R. M., C. M. Coughlin, J. E. Minton and D. L. Davis. 1993. Embryonic survival and variation in embryonic development in gilts and primiparous sows on day 11 of gestation. Fourth international conference on pig reproduction (Missouri, CO) p.19 (Abstr.)

Bodin, L., M. San Cristobal, F. Lecerf, P. Mulsant, B. Bibe, D. Lajous, J. P. Belloc, F. Eychenne, Y. Amigues and J. M. Elsen. 2002. Segregation of a major gene influencing ovulation in progeny of lacaune meat sheep. Genet. Sel. Evol. 34: 447-464.

Bradford, G. E. and H. A. Fitzhugh. 1983. Hair sheep: A general description. In: H.A Fitzhugh and G.E Bradford (Ed.) Hair sheep of Western Africa and the Americas: A genetic resource for the tropics. P 3 . Westview Press Boulder, CO.

Bradford, G. E., H. A. Fitzhugh and A. Dowding. 1983. Reproduction and birth weight of Barbados Blackbelly sheep in Golden Grove Flock, Barbados. In: Hair sheep of Western Africa and the Americas, H. A. Fitzhugh and G. E. Bradford, eds., p. 163. Westview Press Boulder, CO.

Bramley, P. S., H. L. Denehy, and J. E. Newton. 1976. The effect of different planes of nutrition before mating on the reproductive performance of masham ewes. Vet. Rec. 99: 294-296.

Brand, A and W. H. R de jong. 1973. Qualitative and quantitative micromorphological investigations of the tertiary follicle population during the oestrus cycle in sheep. J. Reprod. Fertil. 33: 431-439.

Britt J. H. 1989. Current endocrinological concepts involving embryo transfer. Proceedings of $8^{\text {th }}$ Ann Conv Am Emb Trans Assn. 12-18.

Butcher, R. L. 1972. Aberrant ovulation--consequences on fertility and embryonic 
development. J. Anim Sci. (34 Suppl )1:39-48.

Butcher, R. L., and R. S. Pope. 1979. Role of estrogen during prolonged estrous cycles of the rat on subsequent embryonic death or development. Biol. Reprod. 21: 491495.

Butcher, R.L., J. E. Reber, A. W. Lishman, K. F. Breuel, F. N. Schrick, J. C. Spitzer and E. K. Inskeep. 1992. Maintenance of pregnancy in postpartum beef cows that have short-lived corpora lutea. J. Anim. Sci. 70: 3831-3837.

Cahill, L. P. 1981. Folliculogenesis in the sheep as influenced by breed, season and oestrous cycle. J. Reprod. Fertil. Suppl. 30: 135-142.

Cahill, L. P., and P. Mauleon. 1980. Influences of season, cycle and breed on follicular growth rates in sheep. J. Reprod. Fertil. 58: 321-328.

Cahill, L. P., J. C. Mariana and P. Mauleon. 1979. Total follicular populations in ewes of high and low ovulation rates. J. Reprod. Fertil. 55: 27-36.

Campbell, B. K., D. T. Baird, A. S. McNeilly, and R. J. Scaramuzzi. 1990. Ovarian secretion rates and peripheral concentrations of inhibin in normal and androstenedione-immune ewes with an autotransplanted ovary. J. Endocrinol. 127: 285-296.

Campbell, B. K., R. J. Scaramuzzi, J. A. Downing, and G. Evans. 1990. Steroid secretion rates and plasma binding activity in androstenedione-immune ewes with an autotransplanted ovary. J. Reprod. Fertil. 89: 485-496.

Chupin, D., Y. Combarnous and R. Procureur. 1984. Antagonistic effect of LH on FSH induced superovulation in cattle. Theriogenology 21:229 (Abst).

Cohen-Tannoudji, J., C. Lavenet, A. Locatelli, Y. Tillet, and J. P. Signoret. 1989. Noninvolvement of the accessory olfactory system in the LH response of anoestrous ewes to male odour. J. Reprod. Fertil. 86: 135-144.

Cooper, D. A., D. A. Carver, P. Villeneuve, W. J. Silvia, and E. K. Inskeep. 1991. Effects of progestagen treatment on concentrations of prostaglandins and oxytocin in plasma from the posterior vena cava of post-partum beef cows. J. Reprod. Fertil. 91: 411-421.

Cooperative Regional Research Project.1996. Relationship of fertility to patterns of ovarian follicular development and associated hormonal profiles in dairy cows and heifers. J. Anim. Sci. 74: 1943-1952.

Davis, G. H., K. G. Dodds, R. Wheeler, and N. P. Jay. 2001. Evidence that an imprinted gene on the $x$ chromosome increases ovulation rate in sheep. Biol. Reprod. 64: 216-221.

Deaver, D. R., and R. A. Dailey. 1983. Effects of ovarian secretions and dopamine on secretion of luteinizing hormone and prolactin in ewes. J Anim Sci 57: 978-984.

Deaver, D. R., N. J. Stilley, R. A. Dailey, E. K. Inskeep, and P. E. Lewis. 1986. Concentrations of ovarian and pituitary hormones following prostaglandin $\mathrm{f} 2$ alpha-induced luteal regression in ewes varies with day of the estrous cycle at treatment. J Anim Sci 62: 422-427.

Dixon, A. B. 2003. Late embryonic and fetal mortality in the ewe. Ph.D. Diss., Davis College of Agriculture, Forestry and Consumer Sciences, West Virginia Univ., Morgantown.

di Zerega, G. S., and G. D. Hodgen. 1981. Folliculogenesis in the primate ovarian cycle. Endocr Rev 2: 27-49.

Driancourt, M. A. 1994. Lack of between-follicle interactions in the sheep ovary. Reprod 
Nutr Dev 34: 249-260.

Driancourt M. A., W. R. Gibson and L. P. Cahill. 1984. Follicular dynamics throughout the oestruos cycle in sheep. A Review Reproduction Nutrition Development: 25 $1-15$.

Driancourt, M. A., L. Bodin, O. Boomarov, J. Thimonier, and J. M. Elsen. 1990. Number of mature follicles ovulating after a challenge of human chorionic gonadotropin in different breeds of sheep at different physiological stages. J. Anim. Sci. 68: 719724.

Driancourt, M. A., L. P. Cahill, and B. M. Bindon. 1985. Ovarian follicular populations and preovulatory enlargement in booroola and control merino ewes. J. Reprod. Fertil. 73: 93-107.

Driancourt, M. A., F. Castonguay, B. M. Bindon, L. R. Piper, J. F. Quirke and J. P. Hanrahan. 1990. Ovarian follicular dynamics in lines of sheep (finn, merinos) selected on ovulation rate. J. Anim. Sci. 68: 2034-2041.

Driancourt, M. A., I. K. Gauld, M. Terqui, and R. Webb. 1986. Variations in patterns of follicle development in prolific breeds of sheep. J. Reprod. Fertil. 78: 565-575.

Driancourt, M. A., D. Hermier, and J. P. Hanrahan. 1996. Alterations in follicular function associated with selection on ovulation rate in finn ewes. J. Anim. Sci. 74: 199210.

Driancourt, M. A., R. Webb, and R. C. Fry. 1991. Does follicular dominance occur in ewes? J. Reprod. Fertil. 93: 63-70.

Dufour, J., L. P. Cahill, and P. Mauleon. 1979. Short- and long-term effects of hypophysectomy and unilateral ovariectomy on ovarian follicular populations in sheep. J. Reprod. Fertil. 57: 301-309.

Duggavathi R., P. M. Bartlewski, D. M. Barrett, and N. C. Rawlings. 2001. Assessment of follicular populations and dynamics in the ewe by means of high-resolution ultrasonography. In: Program of the 34 th annual meeting of the society for the study of reproduction; Ottawa, ON. (Abstract 108).

Duggavathi, R., P. M. Bartlewski, D. M. Barrett, and N. C. Rawlings. 2003. Use of highresolution transrectal ultrasonography to assess changes in numbers of small ovarian antral follicles and their relationships to the emergence of follicular waves in cyclic ewes. Theriogenology 60: 495-510.

Duggavathi, R., P. M. Bartlewski, E. Agg, S. Flint, D. M. Barrett, and N. C. Rawlings. 2005. The effect of the manipulation of follicle-stimulating hormone (fsh)-peak characteristics on follicular wave dynamics in sheep: Does an ovarianindependent endogenous rhythm in fsh secretion exist? Biol. Reprod. 72: 14661474.

Dutt, R. H., and L. E. Casida. 1948. Alteration of the estrual cycle in sheep by use of progesterone and its effects upon subsequent ovulation and fertility. Endocrinology 43: 208-217.

Evans, A.C., C. M. Komar, S. A. Wandji and J. E. Fortune. 1997. Changes in androgen secretion and luteinizing hormone pulse amplitude are associated with the recruitment and growth of ovarian follicles during the luteal phase of the bovine estrous cycle. Biol. Reprod. 57:394-401.

Evans, A. C., P. Duffy, N. Hynes, and M. P. Boland. 2000. Waves of follicle development during the estrous cycle in sheep. Theriogenology 53: 699-715. 
Evans, A. C., J. D. Flynn, P. Duffy, P. G. Knight, and M. P. Boland. 2002. Effects of ovarian follicle ablation on fsh, oestradiol and inhibin a concentrations and growth of other follicles in sheep. Reproduction 123: 59-66.

Evans, A. C., P. Duffy, T. F. Crosby, P. A. Hawken, M. P. Boland and A. P. Beard. 2004. Effect of ram exposure at the end of progestagen treatment on estrus synchronisation and fertility during the breeding season in ewes. Anim. Reprod. Sci. 84: 349-358.

Evans, A. C. J. D. Flynn, K. M. Quinn, P. Duffy, P. Quinn, S. Madgwick, T. F. Crosby, M. P. Boland and A. P. Beard. 2001. Ovulation of aged follicles does not affect embryo quality or fertility after a 14-day progestagen estrus synchronization protocol in ewes. Theriogenology 56: 923-936.

Fabre-Nys, C., and G. B. Martin. 1991. Roles of progesterone and oestradiol in determining the temporal sequence and quantitative expression of sexual receptivity and the preovulatory Ih surge in the ewe. J. Endocrinology 130: 367379.

Fitzhugh, H.A and Bradford,G.E.,1983. Productivity of hair sheep and opportunities for improvement. In: H.A. Fitzhugh and G.E. Bradford (Editors), Hair Sheep of Western Africa and the Americas. Westview Press, Boulder, CO, pp. 23-51.

Flynn, J. D., P. Duffy, M. P. Boland, and A. C. Evans. 2000. Progestagen synchronisation in the absence of a corpus luteum results in the ovulation of a persistent follicle in cyclic ewe lambs. Anim. Reprod. Sci. 62: 285-296.

Fry, R. C., and M. A. Driancourt. 1996. Relationships between follicle-stimulating hormone, follicle growth and ovulation rate in sheep. Reprod Fertil Dev 8: 279286.

Galloway, S. M., S. M. Gregan, T. Wilson, K. P. McNatty, J. L. Juengel, O. Ritvos and G. H. Davis. 2002. BMP15 mutations and ovarian function. Mol Cell Endocrinol 191: 15-18.

Garrett, J. E., R. D. Geisert, M. T. Zavy, and G. L. Morgan. 1988. Evidence for maternal regulation of early conceptus growth and development in beef cattle. J. Reprod. Fertil. 84: 437-446.

Gengenbach, D. R., J. E. Hixon, and W. Hansel. 1977. A luteolytic interaction between estradiol and prostaglandin F2alpha in hysterectomized ewes. Biol. Reprod. 16: 571-579.

Gibbons, J. R., K. Kot, D. L. Thomas, M. C. Wiltbank and O. J. Ginther. 1999. Follicular and FSH dynamics in ewes with a history of high and low ovulation rates. Theriogenology 52: 1005-1020.

Ginther, O. J. and K. Kot. 1994. Follicular dynamics during the ovulatory season in goats. Theriogenology 42: 987-1001.

Ginther, O. J., K. Kot, M. C. Wiltbank. 1994. Associations between emergence of follicular waves and fluctuations in FSH concentrations during the estrous cycle in ewes. Therigenology 43: 689-703.

Ginther, O.J., M. C. Wiltbank, P. M. Fricke, J. R. Gibbons and K. Kot. 1994. Selection of the dominant follicle in cattle. Biol. Reprod. 55:1187-1194.

Ginther, O. J., K. Kot, L. J. Kulick, S. Martin and M. C. Wiltbank . 1996. Relationships between FSH and ovarian follicular waves during the last six months of pregnancy in cattle. J Reprod. Fertil. 108: 271-279. 
Godfrey, R. W., M. L. Gray, and J. R. Collins. 1997. A comparison of two methods of oestrous synchronisation of hair sheep in the tropics. Anim. Reprod. Sci. 47: 99106.

Gonzalez de Bulnes, A., J. Santiago-Moreno, R.M. Garcia-Garcia, A. del Campo, A. Gomez-Brunet and A. Lopez-Sebastian. 2001. Origin of the preovulatory follicle in Mouflon sheep (Ovis gmelini musimon) and effect on growth of remaining follicles during the follicular phase of oestrous cycle. Anim. Reprod. Sci. 65: 265272.

Gordon I. 1997. Controlled reproduction in sheep and goats. CAB International, New York.

Goodman, R. L. 1994. Neuroendocrine control of the ovine estrous cycle. Knobil, E. and Neill, J. D. The physiology of Reproduction. ${ }^{\text {nd }}(47), 659-709$. New York, Raven Press.

Goodman, R. L., and F. J. Karsch. 1980. Pulsatile secretion of luteinizing hormone: Differential suppression by ovarian steroids. Endocrinology 107: 1286-1290.

Griffeth R. J., T. M. Nett, P. D. Burns, J. M. Escudero, E. K. Inskeep and G. D. Niswender. 2002. Is luteal production of $\mathrm{PGF}_{2} \mathrm{\alpha}$ required for luteolysis? $35^{\text {th }}$ Annual meeting of the Society for the Study of Reproduction, Baltimore, Maryland. Biol. Reprod. 66 (Suppl. 1 (Abstr. 465).

Henricks, D. M., D. R. Lamond, J. R. Hill, and J. F. Dickey. 1971. Plasma progesterone concentrations before mating and in early pregnancy in the beef heifer. J. Anim. Sci. 33: 450-454.

Horton, G. M. J., S. M. Emanuele, M. B. Solomon, C. C. Burgher and K. E. McClure. 1991. Physiological responses of hair and wool sheep to changes in ambient temperature and feed allowance. In: S.Wildeus (Ed.) Proc. Hair sheep Res. Symp. P331. Univ. Virgin Islands, St. Croix.

Houghton, J. A. S., N. Liberati, F. N. Schrick, E. C. Townsend, R. A. Dailey and E. K. Inskeep. 1995. Day of estrous cycle affects follicular dynamics after induced luteolysis in ewes. J. Anim. Sci. 73: 2094-2101.

Hulet, C. V., H. P. Voightlander, A. L. Pope and Casida. 1956. The nature of earlyseason infertility in sheep. J. Anim. Sci. 15: 607-616.

Johnson, S. K., R. A. Dailey, E. K. Inskeep, and P. E. Lewis. 1996. Effect of peripheral concentrations of progesterone on follicular growth and fertility in ewes. Domest Anim. Endocrinol. 13: 69-79.

Karsch, F. J., S. J. Legan, K. D. Ryan, and D. L. Foster. 1980. Importance of estradiol and progesterone in regulating Ih secretion and estrous behavior during the sheep estrous cycle. Biol. Reprod. 23: 404-413.

Karsch, F. J., D. L. Foster, S. J. Legan, K. D. Ryan, and G. K. Peter. 1979. Control of the preovulatory endocrine events in the ewe: Interrelationship of estradiol, progesterone, and luteinizing hormone. Endocrinology 105: 421-426.

Karsch, F. J., J. W. Noveroske, J. F. Roche, H. W. Norton, and A. V. Nalbandov. 1970. Maintenance of ovine corpora lutea in the absence of ovarian follicles. Endocrinology 87: 1228-1236.

Kastelic, J. P. and O. J. Ginther. 1991. Spontaneous embryonic death on days 20 to 40 in heifers. Theriogenology 35:351-363.

Kieborz-Loos, K. R., H. A. Gaverick, D. H. Keisler, S. A. Hamilton, B. E. Salfen, R. S. Youngquist and M. F. Smith. 2003. Oxytocin-induced secretion of prostaglandin 
f2alpha in postpartum beef cows: Effects of progesterone and estradiol-17beta treatment. J Anim Sci 81: 1830-1836.

Kinder, J. E., F. N. Kojima, E. G. Bergfeld, M. E. Wehrman, and K. E. Fike. 1996. Progestin and estrogen regulation of pulsatile $\mathrm{lh}$ release and development of persistent ovarian follicles in cattle. J. Anim. Sci. 74: 1424-1440.

Kleemann, D. O., and S. K. Walker. 2005. Fertility in south australian commercial merino flocks: Relationships between reproductive traits and environmental cues. Theriogenology 63: 2416-2433.

Knights, M., T. Hoehn, P. E. Lewis, and E. K. Inskeep. 2001. Effectiveness of intravaginal progesterone inserts and fsh for inducing synchronized estrus and increasing lambing rate in anestrous ewes. J. Anim. Sci. 79: 1120-1131.

Knights M., Q. S. Baptiste , A. B.Dixon, J. L. Pate , D. J. Marsh , E. K. Inskeep and P. E. Lewis. 2003. Effects of dosage of FSH, vehicle and time of treatment on ovulation rate and prolificacy in ewes during anestrous season. Small Ruminant Research. 50: 1-9.

Kulick, L. J., D. R. Bergfelt, K. Kot, and O. J. Ginther. 2001. Follicle selection in cattle: Follicle deviation and codominance within sequential waves. Biol. Reprod. 65: 839-846.

Lahlou-Kassi, A., and J. C. Mariana. 1984. Ovarian follicular growth during the oestrous cycle in two breeds of ewes of different ovulation rate, the D'man and the Timahdite. J. Reprod. Fertil. 72: 301-310.

Lamming, G. E., A. O. Darwash, and H. L. Back. 1989. Corpus luteum function in dairy cows and embryo mortality. J. Reprod. Fertil. Suppl. 37: 245-252.

Lee, C. N., and R. L. Ax. 1984. Milk progesterone of dairy cows injected with gonadotropin releasing hormone at the first post partum breeding. Proceedings of the $10^{\text {th }}$ International congress on animal reproduction and A.I., Urbana, IL, (3:401. (Abstr).

Lewis, P. E., and E. K. Inskeep. 1973. Effect of rams on progestin-treated ewes. J. Anim. Sci. 37: 1195-1200.

Lewis, P. E., D. J. Bolt, and E. K. Inskeep. 1974. Luteinizing hormone release and ovulation in anestrous ewes. J. Anim. Sci. 38: 1197-1203.

Leyva, V., B. C. Buckrell, and J. S. Walton. 1998. Regulation of follicular activity and ovulation in ewes by exogenous progestagen. Theriogenology 50: 395-416.

Ligon, R. 1657. A true and exact history of the island of Barbados. London, printed for Humphrey Moseley at the Prince's Armes. pp122.

Lopez-Sebastian, A., A. Gonzalez de Bulnes, J. Santiago-Moreno, A. Gomez-Brunet, E. C. Townsend and E. K. Inskeep. 1997. Patterns of follicular development during the estrous cycle in monovular merino del paris ewes. Anim. Reprod. Sci. 48: 279-291.

Lukaszewska, J., and W. Hansel. 1980. Corpus luteum maintenance during early pregnancy in the cow. J. Reprod. Fertil. 59: 485-493.

Lunstra, D. D., and R. K. Christenson. 1981. Fertilization and embryonic survival in ewes synchronized with exogenous hormones during the anestrous and estrous seasons. J. Anim. Sci. 53: 458-466.

Mandiki, S. N., B. Noel, J. L. Bister, R. Peeters, G. Beerlandt, E. Decuypere, A. Visscher, R. Suess, K. H. Kaulfuss and R. Paquay. 2000. Pre-ovulatory follicular characteristics and ovulation rates in different breeds crosses, carriers or non- 
carriers of the Booroola or Cambridge fecundity gene. Anim. Reprod. Sci. 63: 7788.

Maurer, R. R., and S. E. Echternkamp. 1982. Hormonal Asynchrony and embryonic development. Theriogenology. 17: 11-22.

Marianna J. C., D. Monniaux, M. A. Driancourt and P. Mauleon. 1991. pp. 119-171 Folliculogenesis. In: Cupps, P.T. (Ed.), Reproduction in Domestic Animals. Academic Press, New York.

Martin, G.B., C. M. Oldham and D. R. Lindsay. 1980. Increased plasma LH levels in seasonally anovular Merino ewes following the introduction of rams. Anim. Reprod. Sci. 3: 125-132.

McNatty, K. P., N. L. Hudson, M. Gibb, and F. L. Collins. 1988. Plasma concentrations of $\mathrm{FSH}, \mathrm{LH}$ and progesterone in sheep immunized against an androstenedioneprotein conjugate. J. Reprod. Fertil. 82: 63-69.

McNatty, K. P., D. A. Heath, N. Hudson, and I. J. Clarke. 1990. Effect of long-term hypophysectomy on ovarian follicle populations and gonadotrophin-induced adenosine cyclic 3',5'-monophosphate output by follicles from booroola ewes with or without the f gene. J. Reprod. Fertil. 90: 515-522.

McNatty, K. P., M. Gibb, C. Dobson, K. Ball, J. Coster, D. Heath and D. C. Thurley. 1982. Preovulatory follicular development in sheep treated with pmsg and/or prostaglandin. J. Reprod. Fertil. 65: 111-123.

McNatty, K. P., N. Hudson, K. M. Henderson, M. Gibb, L. Morrison, K. Ball and P. Smith. 1987. Differences in gonadotrophin concentrations and pituitary responsiveness to $\mathrm{GnRH}$ between booroola ewes which were homozygous (ff), heterozygous $(\mathrm{f}+)$ and non-carriers $(++)$ of a major gene influencing their ovulation rate. J. Reprod. Fertil. 80: 577-588.

McNatty, K. P., L. G. Moore, N. L. Hudson, L. D. Quirke, S. B. Lawerence, K. L. Reader, J. P. Hanrahan, P. Smith, N. P. Groome, M. P. Laitinen, O. Ritvos and J. L. Juengel. 2004. The oocyte and its role in regulating ovulation rate: A new paradigm in reproductive biology. Reproduction 128: 379-386.

McNatty, K. P., J. L. Juengel, T. Wilson, S. M. Galloway, G. H. Davis, N. L. Hudson, C. L. Moeller, M. Cranfield, K. L. Reader, M. P. Laitinen, N. P. Groome, H. R. Sawyer and O. Ritvos. 2003. Oocyte-derived growth factors and ovulation rate in sheep. Reprod. Suppl. 61: 339-351.

Mihm, M., N. Curran, P. Hyttle, P. G. Knight, M. P. Boland and J. F. Roche. 1999. Effect of dominant follicle persistence on follicular fluid oestradiol and inhibin and on oocyte maturation in heifers. J. Reprod. Fertil. 116: 293-304.

Mitchell, L. M. W. S. Dingwall, M. J. Mylne, J. Hunton, K. Matthews, F. E. Gebbie, G. J. McCallum and T. G. McEvoy . 2002. Season affects characteristics of the preovulatory LH surge and embryo viability in superovulated ewes. Anim. Reprod. Sci. 74:163-74.

Miller, B. G., and N. W. Moore. 1983. Endometrial protein secretion during early pregnancy in entire and ovariectomized ewes. J. Reprod. Fertil. 68: 137-144.

Montgomery, G. W., S. M. Galloway, G. H. Davis, and K. P. McNatty. 2001. Genes controlling ovulation rate in sheep. Reproduction 121: 843-852.

Moor, R. M. 1968. Effect of embryo on corpus luteum function. J Anim Sci 27 Suppl 1: $97-118$.

Moss G. E. and T. M. Nett . 1980. GnRH interaction with Anterior pituitary.IV. Effect of 
estradiol-17 $\beta$ on $\mathrm{GnRH}$-mediated release of LH from Ovine pituitary cells obtained during the breeding season, anestrous season, and period of transition into or out of the breeding season. 23: 398-403.

Murdoch, W. J., M. De Silva, and T. G. Dunn. 1983. Luteal phase insufficiency in the ewe as a consequence of premature induction of ovulation by intrafollicular injection of gonadotropins. J. Anim. Sci. 57: 1507-1511.

Niswender, G. D., R. H. Schwall, T. A. Fitz, C. E. Farin, and H. R. Sawyer. 1985. Regulation of luteal function in domestic ruminants: New concepts. Recent Prog. Horm. Res. 41: 101-151.

Noel, B., J. L. Bister, and R. Paquay. 1993. Ovarian follicular dynamics in suffolk ewes at different periods of the year. J. Reprod. Fertil. 99: 695-700.

Nottle, M. B., D. O. Kleemann, and R. F. Seamark. 1997. Effect of previous undernutrition on the ovulation rate of merino ewes supplemented with lupin grain. Anim. Reprod. Sci. 49: 29-36.

O'Callaghan, D., A. Donovan, S. J. Sunderland, M. P. Boland, and J. F. Roche. 1994. Effect of the presence of male and female flockmates on reproductive activity in ewes. J. Reprod. Fertil. 100: 497-503.

Oldham, C. M. G. B. Martin and T. W. Knight. 1978. Stimulation of seasonally anovular Merino ewes by rams I. Time from introduction of rams to the preovulatory LH surge and ovulation. Anim. Reprod. Sci. 1: 291-295.

O'Shea, T., B. M. Bindon, M. A. Hillard, L. R. Piper, J. K. Findlay and K. Miyamoto. 1989. Increase in ovulation rate in merino ewes after active immunization with inhibin preparations obtained by immunoaffinity chromatography. Reprod Fertil Dev 1: 347-355.

Ottobre, J.S., G. S. Lewis, W. V. Thayne and E. K. Inskeep. 1980. Mechanism by which progesterone shortens the estrous cycle of the ewe. Biol. Reprod. 5:1046-1053.

Ottobre J. S., D. L. Vincent, W. J. Silvia and E. K. Inskeep . 1984. Aspects of regulation of uterine secretion of prostaglandins during the estrous cycle and early pregnancy. Anim. Reprod. Sci. 7: 75-100.

Oussaid, B., J. C. Mariana, N. Poulin, J. Fontaine P. Lonergan, J. K. Beckers and Y. Cognie. 1999. Reduction of the developmental competence of sheep oocytes by inhibition of $\mathrm{Ih}$ pulses during the follicular phase with a gnrh antagonist. J. Reprod. Fertil. 117: 71-77.

Padmanabhan, V., J. S. Kesner, and E. M. Convey. 1978. Effects of estradiol on basal and luteinizing hormone releasing hormone (lhrh)-induced release of luteinizing hormone (Ih) from bovine pituitary cells in culture. Biol. Reprod. 18: 608-613.

Parsons, S. D., and G. L. Hunter. $1967^{a}$. Effect of the ram on duration of oestrus in the ewe. J. Reprod. Fertil. 14: 61-70.

Parsons, S. D., G. L. Hunter, and A. A. Rayner. $1967^{\mathrm{b}}$. Use of probit analysis in a study of the effect of the ram on time of ovulation in the ewe. J. Reprod. Fertil. 14: 7180.

Patterson, H. C. 1983. Barbados Blackbelly and Crossbred Sheep Performance in a Experimental Flock in Barbados. In: Hair sheep of Western Africa and the Americas, H. A. Fitzhugh and G. E. Bradford, eds., p.103. Westview Press Boulder, CO.

Pearce, G. P., and C. M. Oldham. 1988. Importance of non-olfactory ram stimuli in mediating ram-induced ovulation in the ewe. J. Reprod. Fertil. 84: 333-339. 
Pearce, G. P. and C. M. Oldham. 1985. Corpora lutea with a short life-span induced by rams in seasonally anovular ewes are prevented by progesterone delaying the preovulatory surge of LH. J. Reprod. Fertil. 75: 79-84.

Picton, H. M., C. G. Tsonis, and A. S. McNeilly. 1990. FSH causes a time-dependent stimulation of preovulatory follicle growth in the absence of pulsatile lh secretion in ewes chronically treated with gonadotrophin-releasing hormone agonist. J. Endocrinol. 126: 297-307.

Price, C. A., B. A. Morris, T. O'Shea, and R. Webb. 1987. Active immunization of cattle against partly purified follicular fluid from sheep. J. Reprod. Fertil. 81: 161-168.

Quick, T. C., and B. A. Dehority. 1986. A comparative study of feeding behavior and digestive function in dairy goats, wool sheep and hair sheep. J. Anim. Sci. 63: 1516-1526.

Quinlivan, T. D., C. A. Martin, W. B. Taylor, and I. M. Cairney. 1966. Estimates of preand perinatal mortality in the new zealand romney marsh ewe. I. Pre- and perinatal mortality in those ewes that conceived to one service. J. Reprod. Fertil. 11: 379-390.

Quirke, J. F., G. E. Bradford, T. R. Famula, and D. T. Torrell. 1985. Ovulation rate in sheep selected for weaning weight or litter size. J Anim Sci 61: 1421-1430.

Ravindra, J. P., N. C. Rawlings, A. C. Evans, and G. P. Adams. 1994. Ultrasonographic study of ovarian follicular dynamics in ewes during the oestrous cycle. J. Reprod. Fertil. 101: 501-509.

Reeves, J. J., A. Arimura, and A. V. Schally. 1970. Studies on dose response relationship of luteninizing hormone-releasing hormone (Ih-rh) in sheep. J. Anim. Sci. 31: 933-936.

Reeves, J. J., A. Arimura, and A. V. Schally. 1971. Changes in pituitary responsiveness to luteinizing hormone-releasing hormone (Ih-rh) in anestrous ewes pretreated with estradiol benzoate. Biol. Reprod. 4: 88-92.

Rekwot, P. I., D. Ogwu, E. O. Oyedipe, and V. O. Sekoni. 2001. The role of pheromones and biostimulation in animal reproduction. Anim. Reprod. Sci. 65: 157-170.

Revah, I., and W. R. Butler. 1996. Prolonged dominance of follicles and reduced viability of bovine oocytes. J. Reprod. Fertil. 106: 39-47.

Reynaud, K., J. P. Hanrahan, A. Donovan, and M. A. Driancourt. 1999. Markers of follicle function in belclare-cross ewes differing widely in ovulation rate. J. Reprod. Fertil. 116: 51-61.

Rhind, S. M., J. J. Robinson, C. Fraser, and I. McHattie. 1980. Ovulation and embryo survival rates and plasma progesterone concentrations of prolific ewes treated with pmsg. J. Reprod. Fertil. 58: 139-144.

Rhodes L., and P. W. Nathanielsz. 1988. Comparison of a controlled internal drug release device containing progesterone with intravaginal medroxyprogesterone sponges for estrus synchronization in ewes. Theriogenology. 30: 831-841.

Robinson, T. J. 1954. The necessity for progesterone with estrogen for the induction of recurrent estrus in the ovariectomized ewe. Endocrinology 55: 403-408.

Robinson, T. J. 1954. Relationship of oestrogen and progesterone in oestrous behaviour of the ewe. Nature 173: 878 .

Robinson, T. J. 1955. Quantitative studies on the hormonal induction of oestrus in spayed ewes. J. Endocrinol. 12: 163-173. 
Robinson T.J and F. J. Karsch. 1951. The control of fertility in sheep. Part 11. The augmentation of fertility by gonadotropin treatment of the ewe in the normal breeding season. J. Agric. Sci. Camb. 41: 60-63.

Robinson, T. J. and Smith J. F. 1967. The evaluation of SC-9880-impregnated intravaginal sponges used with or without PMS for the advancement of the breeding season of British Breed ewes. Robinson, T. J. The control of the ovarian cycle in the sheep. $1^{\text {st }}(X V), 208-236$. Sydney, Sydney University Press.

Robinson, T. J., T. D. Quinlivan, and C. Baxter. 1968. The relationship between dose of progestagen and method of preparation of intravaginal sponges on their effectiveness for the control of ovulation in the ewe. J. Reprod. Fertil. 17: 471483.

Roche, J. F., E. J. Austin, M. Ryan, M. O’Rourke, M. Mihm and M. G. Diskin. 1999. Regulation of follicle waves to maximize fertility in cattle. J. Reprod. Fertil. Suppl. 54: 61-71.

Ross, T. T., D. Goode and A. C. Linnerud. 1985. Effects of high ambient temperature on respiration rate, rectal temperature, fetal development and thyroid gland activity in tropical and temperate breeds of sheep. Theriogenology 24:259.

Rubianes, E., R. Ungerfeld, C. Viñoles, A. Rivero and G. P. Adams. 1997. Ovarian response to gonadotropin treatment initiated relative to wave emergence in ultrasongraphically monitered ewes. Theriogenology 47, 1479-1488.

Salamon S. 1976. Artificial Insemination of sheep. Publicity press Ltd., 29-31 Meagher Street, Chippendale, N.S.W. 2008. pp 55-61.

SAS Institute, Inc. 1992. SAS/STAT Users Guide. SAS Institute, Inc. 6. 08. Cary, NC.

Saumande, J., D. Chupin , J. C. Mariana, R. Ortavant and P. Mauléon. 1978. Factors affecting the variability of ovulation rates after PMSG stimulation. In Control of reproduction in the cow. 195-225. Ed. J. M. Sreenan. Martinus Nijhoff, The Hague.

Scaramuzzi, R. J., and D. T. Baird. 1977. Pulsatile release of luteinizing hormone and the secretion of ovarian steroids in sheep during anestrus. Endocrinology 101: 1801-1806.

Scaramuzzi, R. J., D. R. Lindsay, and J. N. Shelton. 1972. Effect of repeated oestrogen administration on oestrous behaviour in ovariectomized ewes. J. Endocrinol. 52: 269-278.

Scaramuzzi, R. J., S. A. Tillson, I. H. Thorneycroft, and B. V. Caldwell. 1971. Action of exogenous progesterone and estrogen on behavioral estrus and luteinizing hormone levels in the ovariectomized ewe. Endocrinology 88: 1184-1189.

Scaramuzzi, R. J., N. R. Adams, D. T. Baird, B. K. Campbell, J. A. Downing, J. K. Findlay, K. M. Henderson, G. B. Martin, K. P. McNatty, A. S. McNeilly and C. G. Tsonis. 1993. A model for follicle selection and the determination of ovulation rate in the ewe. Reprod Fertil Dev 5: 459-478.

Schrick, F. N., R. A. Surface, J. Y. Pritchard, R. A. Dailey, E. C. Townsend and E. K. Inskeep. 1993. Ovarian structures during the estrous cycle and early pregnancy in ewes. Biol. Reprod. 49: 1133-1140.

Sirois, J., and J. E. Fortune. 1988. Follicular dynamics during the estrous cycle in heifers monitored by real time ultrasonography Biology of reproduction 39: 308317.

Smeaton, T. C., and H. A. Robertson. 1971. Studies on the growth and atresia of 
graafian follicles in the ovary of the sheep. J. Reprod. Fertil. 25: 243-252.

Soede, N. M., F. A. Helmond and B. Kemp. 1994. Periovulatory profiles of oestradiol, $\mathrm{LH}$ and progesterone in relation to oestrus and embryo mortality in multiparous sows using transrectal ultrasonography to detect ovulation. J. Reprod. Fertil. 101:633-641.

Southee, J. A., M. G. Hunter, A. S. Law, and W. Haresign. 1988. Effect of hysterectomy on the short life-cycle corpus luteum produced after gnrh-induced ovulation in the anoestrous ewe. J. Reprod. Fertil. 84: 149-155.

Souza, C. J., B. K. Campbell, and D. T. Baird. 1998. Follicular waves and concentrations of steroids and inhibin a in ovarian venous blood during the luteal phase of the oestrous cycle in ewes with an ovarian autotransplant. J. Endocrinol. 156: 563-572.

Spencer, T. E., and F. W. Bazer. 2002. Biology of progesterone action during pregnancy recognition and maintenance of pregnancy. Front Biosci 7: d18791898.

Sreenan J. M., D. Beehan and J. P. Gosling . 1978. Ovarian responses in relation to endocrine status following PMSG stimulation in the cow. 144-159. Ed. J. M. Sreenan. Martinus Nijhoff, The Hague.

Starbuck, M. J., R. A. Dailey, and E. K. Inskeep. 2004. Factors affecting retention of early pregnancy in dairy cattle. Anim. Reprod. Sci. 84: 27-39.

Stock, A. E. and J. E. Fortune. 1993. Ovarian follicular dominance in cattle: relationship between prolonged growth of the ovulatory follicle and endocrine parameters. Endocrinology 132, 1108-1114.

Taft, R., N. Ahmad, and E. K. Inskeep. 1996. Exogenous pulses of luteinizing hormone cause persistence of the largest bovine ovarian follicle. J. Anim. Sci. 74: 29852991.

Thomas, D. L., P. J. Thomford, J. G. Crickman, A. R. Cobb, and P. J. Dziuk. 1987. Effects of plane of nutrition and phenobarbital during the pre-mating period on reproduction in ewes fed differentially during the summer and mated in the fall. J. Anim. Sci. 64: 1144-1152.

Thwaites, C. J. 1967. Embryo mortality in the heat stressed ewe. I. The influence of breed. J. Reprod. Fertil. 14: 5-14.

Turnbull, K. E., A. W. Braden, and P. E. Mattner. 1977. The pattern of follicular growth and atresia in the ovine ovary. Aust J Biol Sci 30: 229-241.

Turnbull, K. E., P. E. Mattner, J. M. George, and R. J. Scaramuzzi. 1978. The relation between patterns of ovarian follicle growth and ovulation rate in sheep. Aust $\mathrm{J}$ Biol Sci 31: 649-655.

Ungerfeld, R., and E. Rubianes . 1999. Effectiveness of short-term progestogen primings for the induction of fertile oestrus with eCG in ewes during late seasonal anoestrus. J. Anim. Sci. 68: 349-353.

Van Cleeff, J., F. J. Karsch, and V. Padmanabhan. 1998. Characterization of endocrine events during the periestrous period in sheep after estrous synchronization with controlled internal drug release (cidr) device. Domest Anim Endocrinol 15: 23-34. Vandeplassche, M., R. Butaye, and R. Bouters. 1979. [the twin capacity of the uterus in heifers and cows (author's transl)]. Dtsch Tierarztl Wochenschr 86: 470-473.

Vincent, D. L., S. Meredith, and E. K. Inskeep. 1986. Advancement of uterine secretion of prostaglandin $\mathrm{e} 2$ by treatment with progesterone and transfer of asynchronous 
embryos. Endocrinology 119: 527-529.

Viñoles, C., A. Meikle, M. Forsberg, and E. Rubianes. 1999. The effect of subluteal levels of exogenous progesterone on follicular dynamics and endocrine patterns during early luteal phase of the ewe. Theriogenology 51: 1351-1361.

Viñoles, C., M. Forsberg, G. Banchero and E. Rubianes. 2001. Effect of long-term and short-term progestagen treatment on follicular development and pregnancy rate in cyclic ewes. Theriogenology. $55: 993-1004$.

Warren L.E., D. N. Ueckert and J. M. Shelton. 1984. Comparative diets of Rambouillet, Barbado, and Karakul sheep and Spanish and Angora goats. J. Range. Manage. 37:172.

Webb, R., I. K. Gauld, and M. A. Driancourt. 1989. Morphological and functional characterization of large antral follicles in three breeds of sheep with different ovulation rates. J. Reprod. Fertil. 87: 243-255.

Webb, R., R. G. Godsen, E. E. Telfer and R. M. Moor . 1999. Factors affecting folliculogenesis in ruminants. J. Anim. Sci. 68: 257-284.

Wilkins, J. F. 1997. Method of stimulating ovulation rate in merino ewes may affect conception but not embryo survival. Anim. Reprod. Sci. 47: 31-42.

Yazwinski, T. A., L. Goode , D. J. Moncal, G. W. Morgan and A. C. Linnerud. 1979. Parasite resistence in straightbred and crossbred Barbados Blackbelly sheep. J. Anim. Sci. 49:919.

Zimbelman, R. G., and L. W. Smith. 1966. Maintenance of pregnancy in ovariectomized heifers with melengestrol acetate. J. Anim. Sci. 25: 207-211.

Zollers, W. G. Jr., H. A. Gaverick, M. F. Smith, R. J. Moffatt, B. E. Salfen and R. S. Youngquist. 1993. Concentrations of progesterone and oxytocin receptors in endometrium of postpartum cows expected to have a short or normal oestrous cycle. J. Reprod. Fertil. 97: 329-337. 